\title{
Transactions
}

\section{Metal-promoted synthesis of amidines containing the model nucleobases 1-methylcytosine and 9-methyladenine $\dagger$}

\author{
Diego Montagner, ${ }^{* a}$ Ennio Zangrando, ${ }^{b}$ Giuseppe Borsato, ${ }^{c}$ Vittorio Lucchini ${ }^{c}$ and Bruno Longato ${ }^{a}$
}

Received 12th April 2011, Accepted 8th June 2011

DOI: 10.1039/c1dt10638d

The amidine complexes $c i s-\left[\mathrm{L}_{2} \mathrm{PtNH}=\mathrm{C}(\mathrm{R})\{1-\mathrm{MeCy}(-2 \mathrm{H})\}\right] \mathrm{NO}_{3}\left(\mathrm{R}=\mathrm{Me}, \mathbf{1 a} ; \mathrm{Ph}, \mathbf{1 b}, \mathrm{Me}_{3} \mathrm{C}, \mathbf{1 c}\right.$; $\left.\mathrm{Ph}_{2}(\mathrm{H}) \mathrm{C}, \mathbf{1 d}\right)$ and $c i s-\left[\mathrm{L}_{2} \mathrm{PtNH}=\mathrm{C}(\mathrm{R})\{9-\mathrm{MeAd}(-2 \mathrm{H})\}\right] \mathrm{NO}_{3}\left(\mathrm{R}=\mathrm{Me}, \mathbf{2 a} ; \mathrm{Ph}, \mathbf{2 b} ; \mathrm{Me}_{3} \mathrm{C}, \mathbf{2 c} ; \mathrm{Ph}_{2}(\mathrm{H}) \mathrm{C}\right.$, 2d), are formed when $c i s-\left[\mathrm{L}_{2} \mathrm{Pt}(\mu-\mathrm{OH})\right]_{2}\left(\mathrm{NO}_{3}\right)_{2}\left(\mathrm{~L}=\mathrm{PPh}_{3}\right)$ reacts with 1-methylcytosine (1-MeCy) and 9-methyladenine (9-MeAd) in solution of $\mathrm{MeCN}, \mathrm{PhCN}, \mathrm{Me}_{3} \mathrm{CCN}$ and $\mathrm{Ph}_{2}(\mathrm{H}) \mathrm{CCN}$. Reaction of 1a,b and $\mathbf{2 a}, \mathbf{b}$ with $\mathrm{HCl}$ affords the protonated amidines $\left[\mathrm{NH}_{2}=\mathrm{C}(\mathrm{R})\{1-\mathrm{MeCy}(-\mathrm{H})\}\right] \mathrm{NO}_{3}(\mathrm{R}=\mathrm{Me}, \mathbf{3 a} ; \mathrm{Ph}$, 3b) and $\left[\mathrm{NH}_{2}=\mathrm{C}(\mathrm{R})\{9-\mathrm{MeAd}(-\mathrm{H})\}\right] \mathrm{NO}_{3}(\mathrm{R}=\mathrm{Me}, \mathbf{4 a} ; \mathrm{Ph}, \mathbf{4 b})$ and cis- $\left(\mathrm{PPh}_{3}\right)_{2} \mathrm{PtCl}_{2}$ in quantitative yield. Treatment of $\mathbf{3 b}$ and $\mathbf{4} \mathbf{b}$ with $\mathrm{NaOH}$ allows the isolation of the neutral benzimidamides $\mathrm{NH}_{2}-\mathrm{C}(\mathrm{Ph})\{1-\mathrm{MeCy}(-2 \mathrm{H})\}(\mathbf{5 b})$ and $\mathrm{NH}_{2}-\mathrm{C}(\mathrm{Ph})\{9-\mathrm{MeAd}(-2 \mathrm{H})\}(\mathbf{6 b})$. In the solid state $3 \mathbf{b}$ shows a planar structure with the hydrogen atom on $\mathrm{N}(4)$ cytosine position involved in a strong $\mathrm{H}$-bond with the $\mathrm{NO}_{3}{ }^{-}$ion. Intermolecular $\mathrm{H}$-bonds between the oxygen of the cytosine ring and one of the $\mathrm{H}$ atoms of the amidine- $\mathrm{NH}_{2}$ group allow the dimerization of the molecule. A detailed analysis of the spectra of 3b in DMF- $d_{7}$ at $-55^{\circ} \mathrm{C}$ indicates the presence of an equilibrium between the species $\left[\mathrm{NH}_{2}=\mathrm{C}(\mathrm{R})\{1-\mathrm{MeCy}(-\mathrm{H})\}\right] \mathrm{NO}_{3}$ and $\left[\mathrm{NH}_{2}=\mathrm{C}(\mathrm{R})\{1-\mathrm{MeCy}(-\mathrm{H})\}\right]_{2}\left(\mathrm{NO}_{3}\right)_{2}$, exchanging with trace amounts of water at $25{ }^{\circ} \mathrm{C}$. $\left[{ }^{15} \mathrm{~N},{ }^{1} \mathrm{H}\right]-\mathrm{HMBC}$ experiments for $\mathbf{5 b}$ and $\mathbf{6 b}$ indicate that the amino tautomer $\mathrm{H}_{2} \mathrm{~N}-\mathrm{C}(\mathrm{Ph})\{$ nucleobase $(-2 \mathrm{H})\}$, is the only detectable in solution and such structure has been confirmed in the solid state. The reaction of $\mathbf{5 b}$ and $\mathbf{6} \mathbf{b}$ with cis- $\mathrm{L}_{2} \mathrm{Pt}\left(\mathrm{ONO}_{2}\right)_{2}\left(\mathrm{~L}=\mathrm{PPh}_{3}\right)$, in chlorinated solvents, determines the immediate appearance of a pale yellow colour due to the coordination of the neutral amidine, likely in its imino form $\mathrm{HN}=\mathrm{C}(\mathrm{Ph})\{$ nucleobase $(-\mathrm{H})\}$, to give the adducts cis- $\left[\mathrm{L}_{2} \mathrm{PtNH}=\mathrm{C}(\mathrm{Ph})\{\text { nucleobase }(-\mathrm{H})\}\right]^{2+}$. In fact, addition of "proton sponge" leads to the immediate deprotonation of the amidine ligand with formation of the starting complexes $\mathbf{1 b}$ and $\mathbf{2} \mathbf{b}$.

\section{Introduction}

Amidines, $\quad \mathrm{R}-\mathrm{C}(=\mathrm{NH}) \mathrm{NH}_{2}$, their $\mathrm{N}$-mono- and $\mathrm{N}, \mathrm{N}^{\prime}-$ disubstituted derivatives are important intermediates in the synthesis of heterocyclic compounds, ${ }^{1}$ some of which are pharmacologically active molecules. ${ }^{2}$ The usual synthetic methods proceed through: i) addition of metal amides to nitriles; ii) addition of salt of ammonia or amines to nitriles; iii) transformation of nitriles into imido esters followed by the condensation with $\mathrm{NH}_{3}$ or amines (Pinner synthesis). ${ }^{1,3}$ In several cases, the preparation needs high temperatures, ${ }^{4}$ strongly reducing agents, ${ }^{5}$ highly acidic or alkaline conditions. ${ }^{6}$

a'Dipartimento di Scienze Chimiche, Università di Padova, Via Marzolo 1, 35131, Padova, Italy. E-mail: diego.montagner@unipd.it; Fax: +39-0498275161; Tel: +39-049-8275172

${ }^{b}$ Dipartimento di Scienze Chimiche e Farmaceutiche, Università di Trieste, Via Giorgieri 1, 34127, Trieste, Italy

'Dipartimento di Scienze Ambientali, Università Ca' Foscari di Venezia, Dorsoduro 2137, 30123, Venezia, Italy

$\dagger$ Electronic supplementary information (ESI) available. CCDC reference numbers 811783-811786. For ESI and crystallographic data in CIF or other electronic format see DOI: 10.1039/c1dt10638d
More recently, the activation of nitriles through coordination to a metal centre, increasing the rate of the nucleophilic attack at the carbon atom of the $\mathrm{CN}$ group, ${ }^{7}$ led to the synthesis of several amidine complexes of transition metals, in particular of platinum(II and IV). ${ }^{8}$ We have recently shown that, if the nucleophile is the nitrogen atom of the $\mathrm{NH}_{2}$-deprotonated 1-methylcytosine (1-MeCy) and 9-methyladenine (9-MeAd) (Chart 1), the azametallacycle complexes of platinum(II) $c i s-\left[\mathrm{L}_{2} \mathrm{PtNH}=\mathrm{C}(\mathrm{R})\{1-\mathrm{MeCy}\right.$ $(-2 \mathrm{H})\}]^{+}$and $c i s-\left[\mathrm{L}_{2} \mathrm{PtNH}=\mathrm{C}(\mathrm{R})\{9-\mathrm{MeAd}(-2 \mathrm{H})\}\right]^{+}\left(\mathrm{L}=\mathrm{PPh}_{3}\right.$ and $\mathrm{PMePh}_{2}$ ) are formed., ${ }^{9,10}$

They contain as an anionic ligand the deprotonated form of the N-monosubstitute amidines $\mathrm{R}-\mathrm{C}(=\mathrm{NH}) \mathrm{NHR}$ ' $(\mathrm{R}=\mathrm{Me}, \mathrm{Ph})$, in which the NHR' group is the nucleobase $1-\mathrm{MeCy}$ or $9-\mathrm{MeAd}$, and are structurally similar to 1,3,5-triazapentadienes recently reviewed by Kopylovich and Pombeiro. ${ }^{11}$

In this paper we present the synthesis and the structural characterization of these new amidines, in their protonated and neutral forms, $\left[\mathrm{NH}_{2}=\mathrm{C}(\mathrm{R})\{\right.$ nucleobase $\left.(-\mathrm{H})\}\right] \mathrm{NO}_{3}$, and $\mathrm{NH}_{2}-$ $\mathrm{C}(\mathrm{R})\{$ nucleobase $(-2 \mathrm{H})\}$, respectively. The ionic species are formed in high yield by protonation of the amidine complexes cis$\left[\mathrm{L}_{2} \mathrm{PtNH}=\mathrm{C}(\mathrm{R})\{\right.$ nucleobase $\left.(-2 \mathrm{H})\}\right] \mathrm{NO}_{3}\left(\mathrm{~L}=\mathrm{PPh}_{3} ; \mathrm{R}=\mathrm{Me}, \mathrm{Ph}\right)$ with aqueous $\mathrm{HCl}$, allowing the quantitative recovery of the 


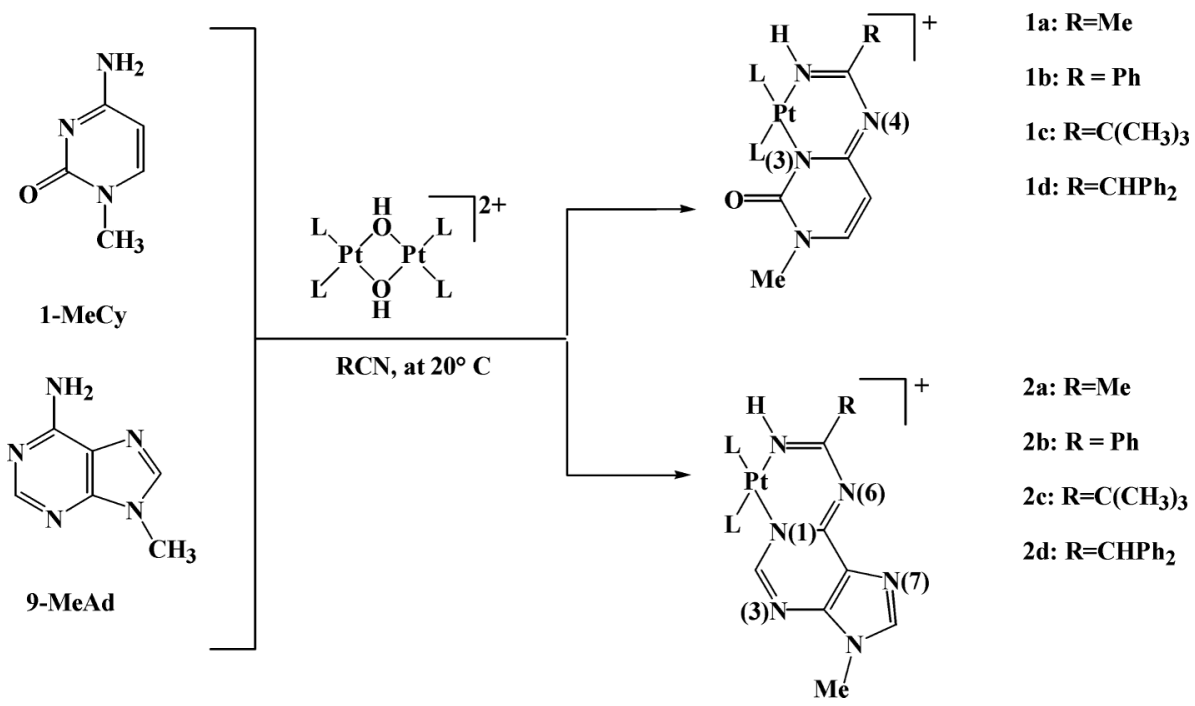

Chart 1 Synthetic procedures for the amidine Platinum(II) complexes ( $\mathrm{L}=\mathrm{PPh}_{3}, \mathrm{PMePh}_{2}$ ).
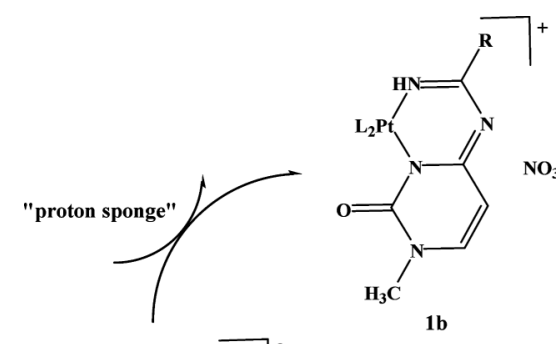

1b
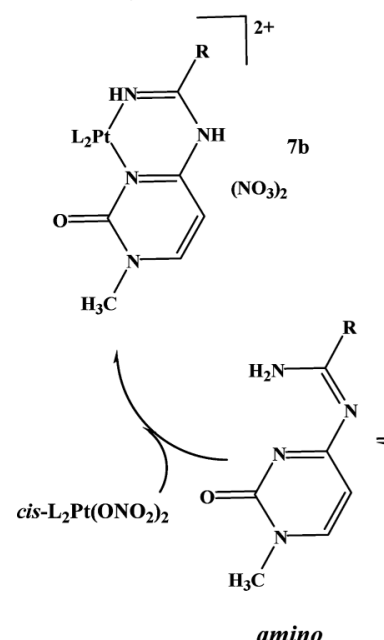

$\mathbf{5 b}$
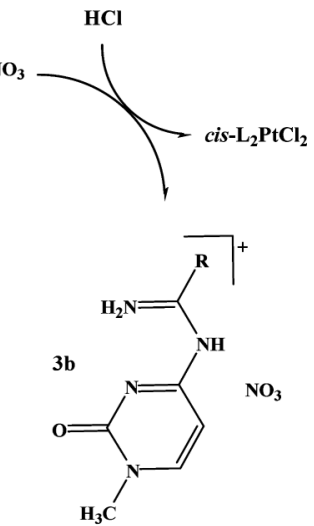

Chart 2 Synthetic pathway for the synthesis of amidines and their coordination properties.

metal as cis- $\left(\mathrm{PPh}_{3}\right)_{2} \mathrm{PtCl}_{2}$, as shown in Chart 2 for the $1-\mathrm{MeCy}$ derivative.

The nitrato salt of $N$-(1-methyl-2-oxo-1,2-dihydropyrimidin4-yl)benzimidamide, $\left[\mathrm{NH}_{2}=\mathrm{C}(\mathrm{Ph})\{1-\mathrm{MeCy}(-\mathrm{H})\}\right] \mathrm{NO}_{3}$, has been characterized by single crystal $\mathrm{X}$-ray analysis and in solution by NMR at variable temperature. In the solid state, strong intermolecular $\mathrm{H}$-bonds stabilize a dimeric structure of the cation, which is also maintained in solution of DMSO- $d_{6}$ or DMF- $d_{7}$.

The neutral species, of which the amino and the imino tautomeric forms are expected $\left[\mathrm{NH}_{2}-\mathrm{C}(\mathrm{R})\{\right.$ nucleobase $(-2 \mathrm{H})\}$ and
$\mathrm{NH}=\mathrm{C}(\mathrm{R})\{$ nucleobase $(-\mathrm{H})\}$, respectively] (Chart 2), have been obtained in the amino form, namely $\mathrm{NH}_{2}-\mathrm{C}(\mathrm{Ph})\{1-\mathrm{MeCy}(-2 \mathrm{H})\}$ and $\mathrm{NH}_{2}-\mathrm{C}(\mathrm{Ph})\{9-\mathrm{MeAd}(-2 \mathrm{H})\}$, and this isomer is the preferred one, as confirmed by the structural characterization in the solid state and in solution. The stabilization of the imino tautomer through metal coordination has been also investigated by reacting these amidines with the complex cis- $\mathrm{L}_{2} \mathrm{Pt}\left(\mathrm{ONO}_{2}\right)_{2}\left(\mathrm{~L}=\mathrm{PPh}_{3}\right)$ containing the labile nitrato ligands. ${ }^{12}$ The adducts, tentatively formulated as $c i s-\left[\mathrm{L}_{2} \mathrm{PtNH}=\mathrm{C}(\mathrm{Ph})\{\right.$ nucleobase $\left.(-\mathrm{H})\}\right]\left(\mathrm{NO}_{3}\right)_{2}$, quantitatively convert into $c i s-\left[\mathrm{L}_{2} \mathrm{PtNH}=\mathrm{C}(\mathrm{Ph})\{\right.$ nucleobase $\left.(-2 \mathrm{H})\}\right] \mathrm{NO}_{3}$, by addition of a "proton sponge".

The single crystal X-ray analysis of the cytosine derivative cis$\left[\left(\mathrm{PPh}_{3}\right)_{2} \mathrm{PtNH}=\mathrm{C}(\mathrm{Ph})\{1-\mathrm{MeCy}(-2 \mathrm{H})\}\right] \mathrm{NO}_{3}$ confirms the coordination features of the anionic ligand previously described for the $\mathrm{PMePh}_{2}$ analogue ${ }^{10}$ and allows the examination of the structural differences between the free and the coordinated benzimidamides. Finally, the reactivity of $\mathrm{Me}_{3} \mathrm{C}-\mathrm{CN}$ and $\mathrm{Ph}_{2}(\mathrm{H}) \mathrm{C}-\mathrm{CN}$ has been explored, showing that the insertion of these hindered nitriles into the platinum-nucleobase bond is incomplete in the case of 9MeAd, while the amidine complexes cis $-\left[\left(\mathrm{PPh}_{3}\right)_{2} \mathrm{PtNH}=\mathrm{C}(\mathrm{R})\{1-\right.$ $\mathrm{MeCy}(-2 \mathrm{H})\}] \mathrm{NO}_{3}\left[\mathrm{R}=\mathrm{Me}_{3} \mathrm{C}\right.$ and $\left.\mathrm{Ph}_{2}(\mathrm{H}) \mathrm{C}\right]$ can been isolated in high yield. They are structurally analogous to the acetonitrile and benzonitrile derivatives, suggesting that the use of appropriate nitriles can lead to a variety of metallacycle complexes from which new amidines can be prepared.

\section{Experimental section}

\section{Instrumentation and materials}

${ }^{1} \mathrm{H},{ }^{13} \mathrm{C}$ and ${ }^{31} \mathrm{P}$ NMR experiments were recorded on a Bruker AVANCE $300 \mathrm{MHz}$ operating at 300.13, 121.49 and 100.61 MHZ, respectively. ${ }^{15} \mathrm{~N}$ NMR with Bruker $400 \mathrm{AMX}-\mathrm{WB}$ spectrometer (operating at $40.6 \mathrm{MHz}$ ). The ${ }^{1} \mathrm{H}$ and ${ }^{13} \mathrm{C}$ chemical shifts were referenced to the residual impurity of the solvent and to TMS. The external references were $\mathrm{H}_{3} \mathrm{PO}_{4}\left(85 \% \mathrm{w} / \mathrm{w}\right.$ in $\left.\mathrm{D}_{2} \mathrm{O}\right)$ for ${ }^{31} \mathrm{P}$ and $\mathrm{CH}_{3} \mathrm{NO}_{2}$ (in $\mathrm{CDCl}_{3}$ at $50 \% \mathrm{w} / \mathrm{w}$ ) for ${ }^{15} \mathrm{~N}$. Inverse detected spectra were obtained through heteronuclear multiple bond correlation 
(HMBC) experiments, using parameters similar to those previously reported. ${ }^{13}$

IR spectra were recorded on a JASCO FT/IR-4100 type A Fourier Transform Infrared Spectrometer using Nujol mulls between $\mathrm{KBr}$ discs.

All the solvents $\left(\mathrm{CH}_{2} \mathrm{Cl}_{2}, \mathrm{MeOH}, \mathrm{PhCN}, \mathrm{CDCl}_{3}, \mathrm{D}_{2} \mathrm{O}\right.$, DMSO- $\left.d_{6}, \mathrm{DMF}-d_{7}\right), \mathrm{HCl}, \mathrm{NaOH}, \mathrm{Ph}_{2} \mathrm{C}(\mathrm{H}) \mathrm{CN},\left(\mathrm{CH}_{3}\right)_{3} \mathrm{CCN}$ and $\mathrm{CH}\left(\mathrm{OC}_{2} \mathrm{H}_{5}\right)_{3}$ are Aldrich products. $9-\mathrm{MeAd},{ }^{14} 1-\mathrm{MeCy},{ }^{15}$ cis$\left[\left(\mathrm{PPh}_{3}\right)_{2} \mathrm{Pt}(\mu-\mathrm{OH})\right]_{2}\left(\mathrm{NO}_{3}\right)_{2},{ }^{9} \quad c i s-\left[\left(\mathrm{PPh}_{3}\right)_{2} \mathrm{PtNH}=\mathrm{C}(\mathrm{R})\{1-\mathrm{MeCy}\right.$ $(-2 \mathrm{H})\}] \mathrm{NO}_{3}(\mathrm{R}=\mathrm{Me}, \mathbf{1 a} ; \mathrm{Ph}, \mathbf{1 b})$ and $c i s-\left[\left(\mathrm{PPh}_{3}\right)_{2} \mathrm{PtNH}=\mathrm{C}(\mathrm{Ph})\{9-\right.$ $\operatorname{MeAd}(-2 \mathrm{H})\} \mathrm{NO}_{3}(\mathrm{R}=\mathrm{Me}, \mathbf{2} \mathbf{a} ; \mathbf{P h}, \mathbf{2 b})$ were synthesized as previously reported. ${ }^{9,10}$

\section{Synthetic work}

1. $\quad c i s-\left[\left(\mathrm{PPh}_{3}\right)_{2} \mathrm{PtHN}=\mathrm{C}\left(\mathrm{CMe}_{3}\right)\{1-\mathrm{MeCy}(-2 \mathrm{H})\}\right] \mathrm{NO}_{3}$, 1c. $\mathrm{A}$ suspension of cis-[( $\left.\left.\mathrm{PPh}_{3}\right)_{2} \mathrm{Pt}(\mu-\mathrm{OH})\right]_{2}\left(\mathrm{NO}_{3}\right)_{2}\left(32 \mathrm{mg}, 2.0 \times 10^{-2}\right.$ $\mathrm{mmol})$ and 1-MeCy $\left(5.2 \mathrm{mg}, 4.0 \times 10^{-2} \mathrm{mmol}\right)$ in $\left(\mathrm{CH}_{3}\right)_{3} \mathrm{CCN}$ ( $2 \mathrm{~mL})$ and $\mathrm{CH}_{2} \mathrm{Cl}_{2}(4 \mathrm{~mL})$ was stirred at r.t. for $24 \mathrm{~h}$. Addition of $\mathrm{Et}_{2} \mathrm{O}$ to the resulting yellow solution afforded the precipitation of a pale yellow solid, which was recovered by filtration, washed several times with $\mathrm{Et}_{2} \mathrm{O}$, and dried under vacuum. The yield of 1c was $32 \mathrm{mg}, 80 \%$. Elemental analysis calcd (\%) for $\mathrm{C}_{46} \mathrm{H}_{45} \mathrm{~N}_{5} \mathrm{O}_{4}$ $\mathrm{P}_{2} \mathrm{Pt} .1 / 2 \mathrm{CH}_{2} \mathrm{Cl}_{2}$ : C 54.15, H 4.50, N 6.79; found C 54.62, H 4.66, $\mathrm{N}$ 7.02. ${ }^{1} \mathrm{H}$ NMR in $\mathrm{CDCl}_{3}(\delta, \mathrm{ppm}): 7.50-7.21$ (c.m., $\left.30 \mathrm{H}, \mathrm{Ph}\right)$; $7.12\left(\mathrm{~d},{ }^{3} J_{\mathrm{HH}}=7.2 \mathrm{~Hz}, 1 \mathrm{H}, \mathrm{H} 6\right) ; 6.03\left(\mathrm{dd},{ }^{3} J_{\mathrm{HH}}=7.1 \mathrm{~Hz},{ }^{5} J_{\mathrm{HP}}=\right.$ $1.5 \mathrm{~Hz}, 1 \mathrm{H}, \mathrm{H} 5) ; 5.89$ (br s, $1 \mathrm{H}, \mathrm{NH}$ ); 2.65 (s, $3 \mathrm{H}, \mathrm{N}(1) \mathrm{CH}_{3}$ ); $0.86\left(\mathrm{~s}, 9 \mathrm{H}, \mathrm{CMe}_{3}\right) .{ }^{31} \mathrm{P}\left\{{ }^{1} \mathrm{H}\right\} \mathrm{NMR}$ in DMSO- $d_{6}(\delta, \mathrm{ppm}): 8.29$ $\left({ }^{1} J_{\mathrm{PPt}}=3436 \mathrm{~Hz}\right) ; 8.01\left({ }^{1} J_{\mathrm{PPt}}=3479 \mathrm{~Hz}\right),{ }^{2} J_{\mathrm{PP}}=24.9 \mathrm{~Hz} .{ }^{1} \mathrm{H} \mathrm{NMR}$ in DMSO- $d_{6}(\delta, \mathrm{ppm}): 7.79-7.30$ (c.m., $\left.30 \mathrm{H}, \mathrm{Ph}\right) ; 7.27\left(\mathrm{~d},{ }^{3} J_{\mathrm{HH}}=\right.$ $7.4 \mathrm{~Hz}, 1 \mathrm{H}, \mathrm{H} 6) ; 5.92\left(\mathrm{dd},{ }^{3} J_{\mathrm{HH}}=7.4 \mathrm{~Hz},{ }^{5} J_{\mathrm{HP}}=1.0 \mathrm{~Hz} 1 \mathrm{H}, \mathrm{H} 5\right)$; 5.84 (br s, $1 \mathrm{H}, \mathrm{NH}) ; 3.35$ (s, $3 \mathrm{H}, \mathrm{N}(1) \mathrm{CH}_{3}: 0.78$ (s, 9H, $\mathrm{CMe}_{3}$ ).

2. $c i s-\left[\left(\mathbf{P P h}_{3}\right)_{2} \mathbf{P t H N}=\mathbf{C}\left(\mathrm{CHPh}_{2}\right)\{1-\mathrm{MeCy}(-2 \mathrm{H})\}\right] \mathrm{NO}_{3}, \quad 1 \mathrm{~d}$. A suspension of $c i s-\left[\left(\mathrm{PPh}_{3}\right)_{2} \mathrm{Pt}(\mu-\mathrm{OH})\right]_{2}\left(\mathrm{NO}_{3}\right)_{2}\left(502 \mathrm{mg}, 3.1 \times 10^{-1}\right.$ mmol), 1-MeCy (79.2 mg, $\left.6.3 \times 10^{-1} \mathrm{mmol}\right)$ and $\mathrm{Ph}_{2} \mathrm{C}(\mathrm{H}) \mathrm{CN}$ (128 mg, $\left.6.6 \times 10^{-1} \mathrm{mmol}\right)$ in $\mathrm{CH}_{2} \mathrm{Cl}_{2}(5.0 \mathrm{~mL})$ was stirred at ca $25{ }^{\circ} \mathrm{C}$ for 3 days. A trace amount of solid was eliminated by filtration and $\mathrm{Et}_{2} \mathrm{O}(20 \mathrm{~mL})$ was then added to the resulting yellow solution. The powdered precipitate was recovered by filtration, washed several times with $\mathrm{Et}_{2} \mathrm{O}$, and dried under vacuum, to give a yellow solid. The yield of $\mathbf{1 d}$ was $585 \mathrm{mg}, 92 \%$. Elemental analysis calcd (\%) for $\mathrm{C}_{55} \mathrm{H}_{47} \mathrm{~N}_{5} \mathrm{O}_{4} \mathrm{P}_{2} \mathrm{Pt} \cdot \mathrm{CH}_{2} \mathrm{Cl}_{2}$ : C 56.81, $\mathrm{H} 4.18$, $\mathrm{N}$ 5.91; found $\mathrm{C} 56.49, \mathrm{H} 4.21, \mathrm{~N} 6.09 .{ }^{1} \mathrm{H} \mathrm{NMR}$ in $\mathrm{CDCl}_{3}(\delta$, ppm): 7.62-6.68 (c.m., $41 \mathrm{H}, \mathrm{Ph}$ and H6); 6.07 (br s, 1H, NH; $5.93\left(\mathrm{dd},{ }^{3} J_{\mathrm{HH}}=7.1 \mathrm{~Hz},{ }^{5} J_{\mathrm{HP}}=1.2 \mathrm{~Hz} 1 \mathrm{H}, \mathrm{H} 5\right) ; 5.18(\mathrm{~s}, 1 \mathrm{H}, \mathrm{CH})$; $2.68\left(\mathrm{~s}, 3 \mathrm{H}, \mathrm{N}(1) \mathrm{CH}_{3} \cdot{ }^{31} \mathrm{P}\left\{{ }^{1} \mathrm{H}\right\} \mathrm{NMR}\right.$ in DMSO- $d_{6}(\delta, \mathrm{ppm}): 7.71$ $\left({ }^{1} J_{\mathrm{PPt}}=3523 \mathrm{~Hz}\right) ; 7.27\left({ }^{1} J_{\mathrm{PPt}}=3402 \mathrm{~Hz}\right),{ }^{2} J_{\mathrm{PP}}=25.3 \mathrm{~Hz} .{ }^{1} \mathrm{H} \mathrm{NMR}$ in DMSO- $d_{6}(\delta, \mathrm{ppm})$ : 7.75-6.75 (c.m., $41 \mathrm{H}, \mathrm{Ph}$ and H6); 6.28 (br s, $1 \mathrm{H}, \mathrm{NH}) ; 5.86\left(\mathrm{dd},{ }^{3} J_{\mathrm{HH}}=7.1 \mathrm{~Hz},{ }^{5} J_{\mathrm{HP}}=1.2 \mathrm{~Hz} 1 \mathrm{H}, \mathrm{H} 5\right)$; $5.28(\mathrm{~s}, 1 \mathrm{H}, \mathrm{CH}) ; 3.35$ (s, 3H, N(1) $\left.\mathrm{CH}_{3}\right)$.

3. $\left[\mathbf{N H}_{2}=\mathbf{C}(\mathbf{P h})\{\mathbf{1 - M e C y}(-\mathbf{H})\}\right] \mathbf{N O}_{3}, 3 \mathbf{b}$. To a solution of $\mathbf{1 b}$ (215 mg, $\left.2.1 \times 10^{-1} \mathrm{mmol}\right)$ in $\mathrm{CH}_{2} \mathrm{Cl}_{2}(10 \mathrm{~mL})$, a solution of $\mathrm{HCl}$ $0.05 \mathrm{M}\left(8.53 \mathrm{~mL}, 4.3 \times 10^{-1} \mathrm{mmol}\right)$ was slowly added and the mixture let stirring for $2 \mathrm{~h}$ at r.t. The aqueous phase was then separated through a separating funnel and the solvent evaporated under vacuum at ambient temperature. The resulting white solid 3b was $54.4 \mathrm{mg}$ (yield $89 \%$ ). Elemental analysis calcd (\%) for $\mathbf{3 b}$; $\mathrm{C}_{12} \mathrm{H}_{13} \mathrm{~N}_{5} \mathrm{O}_{4}$ : C 49.48, $\mathrm{H} 4.51, \mathrm{~N} 24.03$; found $\mathrm{C} 49.30, \mathrm{H} 4.68$,
$\mathrm{N}$ 23.85. ${ }^{1} \mathrm{H}$ NMR in $\mathrm{D}_{2} \mathrm{O}(\delta, \mathrm{ppm}): 8.13\left(\mathrm{~d},{ }^{3} J_{\mathrm{HH}}=7.1 \mathrm{~Hz}, 1 \mathrm{H}\right.$, H6); 7.81-7.59 (c.m., 5H, Ph); 6.50 (d, $\left.{ }^{3} J_{\mathrm{HH}}=7.1 \mathrm{~Hz}, 1 \mathrm{H}, \mathrm{H} 5\right)$; $3.53\left(\mathrm{~s}, 3 \mathrm{H}, \mathrm{N}(1) \mathrm{CH}_{3}\right) .{ }^{13} \mathrm{C}\left\{{ }^{1} \mathrm{H}\right\} \mathrm{NMR}$ in $\mathrm{D}_{2} \mathrm{O}(\delta, \mathrm{ppm}): 166.8$ $\left(\mathrm{C}_{\mathrm{CN}}\right) ; 158.3(\mathrm{C} 2)$; $153.8(\mathrm{C} 8) ; 135.0\left(\mathrm{C}_{\mathrm{p}}\right) ; 130.2\left(\mathrm{C}_{\mathrm{m}}\right) ; 129.3\left(\mathrm{C}_{\mathrm{o}}\right)$; $128.1\left(\mathrm{C}_{\mathrm{i}}\right) ; 99.2(\mathrm{C} 5) ; 39.1\left(\mathrm{NCH}_{3}\right) .{ }^{1} \mathrm{H}$ NMR in DMSO- $d_{6}(\delta$, ppm): 12.12 (br s, $1 \mathrm{H}, \mathrm{NH}$ ); 11.87 (br s, 1H, NH); 9.81 (br s, $1 \mathrm{H}, \mathrm{NH}) ; 8.26\left(\mathrm{~d},{ }^{3} J_{\mathrm{HH}}=7.5 \mathrm{~Hz}, 1 \mathrm{H}, \mathrm{H} 6\right) ; 7.97-7.88$ (c.m., $5 \mathrm{H}$, $\mathrm{Ph}) ; 6.48\left(\mathrm{~d},{ }^{3} J_{\mathrm{HH}}=7.5 \mathrm{~Hz}, 1 \mathrm{H}, \mathrm{H} 5\right) ; 3.44$ (s, $\left.3 \mathrm{H}, \mathrm{N}(1) \mathrm{CH}_{3}\right)$. IR: $v_{\mathrm{NH}}=3458$ and $3229 \mathrm{~cm}^{-1} ; v_{\mathrm{CO}}=1651 \mathrm{~cm}^{-1}$. Suitable crystals for $\mathrm{X}$-ray analysis were obtained from slow diffusion of $\mathrm{Et}_{2} \mathrm{O}$ vapors into a $\mathrm{MeOH}$ solution of $\mathbf{3 b}$, at r.t. With the same procedure, 3a was obtained starting from cis-[( $\left.\mathrm{PPh}_{3}\right)_{2} \mathrm{PtHN}=\mathrm{C}(\mathrm{Me})\{1-\mathrm{MeCy}$ $(-2 \mathrm{H})\}] \mathrm{NO}_{3}$. (yield 75\%). Elemental analysis calcd (\%) for 3a; $\mathrm{C}_{7} \mathrm{H}_{11} \mathrm{~N}_{5} \mathrm{O}_{4}$ : C 36.68, $\mathrm{H} 4.85, \mathrm{~N} 30.54$; found $\mathrm{C} 36.40, \mathrm{H} 4.70, \mathrm{~N}$ 30.85. ${ }^{1} \mathrm{H}$ NMR in $\mathrm{D}_{2} \mathrm{O}(\delta, \mathrm{ppm}): 8.13\left(\mathrm{~d},{ }^{3} J_{\mathrm{HH}}=7.05 \mathrm{~Hz}, 1 \mathrm{H}\right.$, H6); $6.40\left(\mathrm{~d},{ }^{3} J_{\mathrm{HH}}=7.05 \mathrm{~Hz}, 1 \mathrm{H}, \mathrm{H} 5\right) ; 3.57$ (s, $\left.3 \mathrm{H}, \mathrm{N}(1) \mathrm{CH}_{3}\right) ; 2.48$ $\left(\mathrm{s}, 3 \mathrm{H}, \mathrm{CCH}_{3}\right) .{ }^{1} \mathrm{H}$ NMR in DMSO- $d_{6}(\delta, \mathrm{ppm}): 11.22(\mathrm{br} \mathrm{s}, 1 \mathrm{H}$, $\mathrm{NH}) ; 11.12$ (br s, $1 \mathrm{H}, \mathrm{NH}) ; 11.08$ (br s, $1 \mathrm{H}, \mathrm{NH}) ; 8.24\left(\mathrm{~d},{ }^{3} J_{\mathrm{HH}}=\right.$ $6.51 \mathrm{~Hz}, 1 \mathrm{H}, \mathrm{H} 6) ; 6.22\left(\mathrm{~d},{ }^{3} J_{\mathrm{HH}}=6.51 \mathrm{~Hz}, 1 \mathrm{H}, \mathrm{H} 5\right) ; 3.51(\mathrm{~s}, 3 \mathrm{H}$, $\left.\mathrm{N}(1) \mathrm{CH}_{3}\right) ; 2.42\left(\mathrm{~s}, 3 \mathrm{H}, \mathrm{CCH}_{3}\right)$.

4. $\left[\mathbf{N H}_{2}=\mathbf{C}(\mathbf{P h})\{\mathbf{9}-\mathrm{MeAd}(-\mathbf{H})\}\right] \mathbf{N O}_{3}, \mathbf{4 b}$. With an analogue procedure, starting from $\mathbf{2 b}\left(136 \mathrm{mg}, 1.3 \times 10^{-1} \mathrm{mmol}\right)$, $\mathbf{4 b}$ was prepared (55 mg, yield $89 \%$ ). Elemental analysis calcd (\%) for $\mathbf{4 b}$; $\mathrm{C}_{13} \mathrm{H}_{13} \mathrm{~N}_{7} \mathrm{O}_{3}: \mathrm{C} 49.53, \mathrm{H} 4.16, \mathrm{~N} 31.08$; found $\mathrm{C} 49.32, \mathrm{H} 4.34, \mathrm{~N}$ 31.25. ${ }^{1} \mathrm{H}$ NMR in $\mathrm{D}_{2} \mathrm{O}(\delta, \mathrm{ppm}): 8.79(\mathrm{~s}, 1 \mathrm{H}, \mathrm{H} 2) ; 8.36(\mathrm{~s}, 1 \mathrm{H}, \mathrm{H} 8)$; $7.91-7.64$ (c.m., 5H, Ph); 3.39 (s, 3H, N(9) $\left.\mathrm{CH}_{3}\right) .{ }^{13} \mathrm{C}\left\{{ }^{1} \mathrm{H}\right\} \mathrm{NMR}$ in $\mathrm{D}_{2} \mathrm{O}(\delta, \mathrm{ppm})$ : $162.7\left(\mathrm{C}_{\mathrm{CN}}\right) ; 159.7(\mathrm{C} 2) ; 153.3(\mathrm{C} 6) ; 151.3(\mathrm{C} 4)$; 147.9 (C8); $135.4(\mathrm{C} 5) ; 132.5\left(\mathrm{C}_{\mathrm{p}}\right) ; 130.2\left(\mathrm{C}_{\mathrm{m}}\right) ; 129.1\left(\mathrm{C}_{\mathrm{o}}\right) ; 128.9$ $\left(\mathrm{C}_{\mathrm{i}}\right) ; 99.2(\mathrm{C} 5) ; 30.9\left(\mathrm{NCH}_{3}\right) .{ }^{1} \mathrm{H}$ NMR in DMSO- $d_{6}(\delta, \mathrm{ppm})$ : 11.68 (br s, 1H, NH); 10.96 (br s, 2H, NH); 8.87 (s, 1H, H2); 8.68 (s, $1 \mathrm{H}, \mathrm{H} 8$ ); 7.91-7.77 (c.m., 5H, Ph); 3.90 (s, $3 \mathrm{H}, \mathrm{N}(9) \mathrm{CH}_{3}$ ). IR: $v_{\mathrm{NH}}=3453$ and $3223 \mathrm{~cm}^{-1}$. With the same procedure, 4a was obtained starting from cis- $\left[\left(\mathrm{PPh}_{3}\right)_{2} \mathrm{PtHN}=\mathrm{C}(\mathrm{Me})\{9-\mathrm{MeAd}\right.$ $(-2 \mathrm{H})\}] \mathrm{NO}_{3}$. (yield 79\%). Elemental analysis calcd (\%) for 4a; $\mathrm{C}_{8} \mathrm{H}_{11} \mathrm{~N}_{7} \mathrm{O}_{3}$ : C 37.95, H 4.39, N 38.71; found C 38.20, H 4.45, N 38.42. ${ }^{1} \mathrm{H}$ NMR in $\mathrm{D}_{2} \mathrm{O}(\delta, \mathrm{ppm}): 8.77(\mathrm{~s}, 1 \mathrm{H}, \mathrm{H} 2) ; 8.39(\mathrm{~s}, 1 \mathrm{H}$, $\mathrm{H} 8) ; 3.93$ (s, $\left.3 \mathrm{H}, \mathrm{N}(1) \mathrm{CH}_{3}\right) ; 2.61\left(\mathrm{~s}, 3 \mathrm{H}, \mathrm{CCH}_{3}\right) .{ }^{1} \mathrm{H} \mathrm{NMR}$ in DMSO- $d_{6}(\delta, \mathrm{ppm}): 11.56$ (br s, $\left.1 \mathrm{H}, \mathrm{NH}\right) ; 10.94$ (br s, $\left.1 \mathrm{H}, \mathrm{NH}\right)$; 8.70 (br s, 1H, NH); 8.94 (s, 1H, H2); 8.79 (s, 1H, H8); 3.87 (s, 3H, $\left.\mathrm{N}(1) \mathrm{CH}_{3}\right) ; 2.52\left(\mathrm{~s}, 3 \mathrm{H}, \mathrm{CCH}_{3}\right)$.

5. $\mathbf{H}_{2} \mathbf{N}-\mathbf{C}(\mathbf{P h})\{\mathbf{1 - M e C y}(-2 \mathrm{H})\}$, 5b. To a solution of $\mathbf{3 b}$ $\left(120 \mathrm{mg}, 4.1 \times 10^{-1} \mathrm{mmol}\right)$ in $\mathrm{H}_{2} \mathrm{O}(4 \mathrm{~mL})$ a solution of $\mathrm{NaOH}$ $0.1 \mathrm{M}(4.1 \mathrm{~mL})$ was added. The white precipitate that immediately formed was recovered by filtration, washed several times with $\mathrm{H}_{2} \mathrm{O}$ and dried under vacuum. The yield of $\mathbf{5 b}$ was $85 \%$. Elemental analysis calcd (\%) for $\mathbf{5 b} ; \mathrm{C}_{12} \mathrm{H}_{12} \mathrm{~N}_{4} \mathrm{O}: \mathrm{C}$ 63.15, $\mathrm{H}$ 5.31, N 24.53; found $\mathrm{C} 62.96, \mathrm{H} 5.05, \mathrm{~N} 24.38 .{ }^{1} \mathrm{H} \mathrm{NMR}$ in $\mathrm{CDCl}_{3}(\delta, \mathrm{ppm})$ : 11.56 (br s, $1 \mathrm{H}, \mathrm{NH}) ; 7.95-7.44$ (c.m., $5 \mathrm{H}, \mathrm{Ph}) ; 7.42\left(\mathrm{~d},{ }^{3} J_{\mathrm{HH}}=\right.$ $6.9 \mathrm{~Hz}, 1 \mathrm{H}, \mathrm{H} 6) ; 7.14$ (br s, $1 \mathrm{H}, \mathrm{NH}) ; 6.25\left(\mathrm{~d},{ }^{3} J_{\mathrm{HH}}=6.9 \mathrm{~Hz}, 1 \mathrm{H}\right.$, $\mathrm{H} 5) ; 3.52$ (s, $\left.3 \mathrm{H}, \mathrm{N}(1) \mathrm{CH}_{3}\right) .{ }^{13} \mathrm{C}\left\{{ }^{1} \mathrm{H}\right\}$ NMR in $\mathrm{CDCl}_{3}(\delta, \mathrm{ppm})$ : $173.0\left(\mathrm{C}_{\mathrm{CN}}\right) ; 165.1(\mathrm{C} 4) ; 157.6(\mathrm{C} 2) ; 146.0(\mathrm{C} 6) ; 135.3\left(\mathrm{C}_{\mathrm{p}}\right) ; 131.0$ $\left(\mathrm{C}_{\mathrm{m}}\right) ; 128.5\left(\mathrm{C}_{\mathrm{o}}\right) ; 127.8\left(\mathrm{C}_{\mathrm{i}}\right) ; 105.1(\mathrm{C} 5) ; 38.3\left(\mathrm{NCH}_{3}\right) .{ }^{1} \mathrm{H}$ NMR in DMSO- $d_{6}(\delta, \mathrm{ppm}): 11.11$ (br s, $\left.1 \mathrm{H}, \mathrm{NH}\right) ; 9.14$ (br s, $\left.1 \mathrm{H}, \mathrm{NH}\right)$; 8.03-7.57 (c.m., 5H, Ph); 7.87 (d, $\left.{ }^{3} J_{\mathrm{HH}}=7.0 \mathrm{~Hz}, 1 \mathrm{H}, \mathrm{H} 6\right) ; 6.06$ (d, $\left.{ }^{3} J_{\mathrm{HH}}=7.0 \mathrm{~Hz}, 1 \mathrm{H}, \mathrm{H} 5\right) ; 3.32\left(\mathrm{~s}, 3 \mathrm{H}, \mathrm{N}(1) \mathrm{CH}_{3}\right)$. IR: $v_{\mathrm{NH}}=3444$ and $3183 \mathrm{~cm}^{-1}$. 
6. $\mathbf{H}_{2} \mathbf{N}-\mathbf{C}(\mathbf{P h})\{9-M e A d(-2 H)\}$, 6b. To a solution of $\mathbf{4 b}$ (184 mg, $\left.5.8 \times 10^{-1} \mathrm{mmol}\right)$ in $\mathrm{H}_{2} \mathrm{O}(6 \mathrm{~mL})$ a solution of $\mathrm{NaOH} 0.1 \mathrm{M}$ $(5.90 \mathrm{~mL})$ was slowly added. The white precipitate immediately formed was recovered by filtration, washed with $\mathrm{H}_{2} \mathrm{O}$ and dried under vacuum. The yield of $6 \mathbf{b}$ was $97 \mathrm{mg}, 66 \%$. Elemental analysis calcd (\%) for $\mathbf{6 b} ; \mathrm{C}_{13} \mathrm{H}_{12} \mathrm{~N}_{6}$ : C 61.90, $\mathrm{H} 4.80, \mathrm{~N} 33.30$; found $\mathrm{C}$ 62.15, H 4.62, N 33.52. ${ }^{1} \mathrm{H}$ NMR in $\mathrm{CDCl}_{3}(\delta, \mathrm{ppm}): 11.10$ (br s, $1 \mathrm{H}, \mathrm{NH}$ ); 8.69 (s, 1H, H2); 8.11-7.45 (c.m., $6 \mathrm{H}, \mathrm{Ph}$ and H8); 5.95 (br s, $1 \mathrm{H}, \mathrm{NH}) ; 3.89$ (s, $\left.3 \mathrm{H}, \mathrm{N}(9) \mathrm{CH}_{3}\right) .{ }^{13} \mathrm{C}\left\{{ }^{1} \mathrm{H}\right\} \mathrm{NMR}$ in $\mathrm{CDCl}_{3}(\delta, \mathrm{ppm}): 163.4\left(\mathrm{C}_{\mathrm{CN}}\right) ; 160.0(\mathrm{C} 2) ; 152.7(\mathrm{C} 6) ; 151.8(\mathrm{C} 4)$; 143.5 (C8); $136.5(\mathrm{C} 5) ; 132.4\left(\mathrm{C}_{\mathrm{p}}\right) ; 129.3\left(\mathrm{C}_{\mathrm{m}}\right) ; 128.7\left(\mathrm{C}_{\mathrm{o}}\right) ; 128.4$ $\left(\mathrm{C}_{\mathrm{i}}\right) ; 30.6\left(\mathrm{NCH}_{3}\right) .{ }^{1} \mathrm{H}$ NMR in DMSO-d $(\delta, \mathrm{ppm}): 10.25$ (br s, 1H, NH); 8.79 (br s, 1H, NH); 8.63 (s, 1H, H2); 8.28 (s, 1H, H8); 8.13-7.57 (c.m., $5 \mathrm{H}, \mathrm{Ph}$ ); 3.79 (s, 3H, N(9) $\mathrm{CH}_{3}$ ). IR: $v_{\mathrm{NH}}=3466$ and $3252 \mathrm{~cm}^{-1}$.

Suitable crystals for X-ray analyses of $\mathbf{5 b}$ and $\mathbf{6} \mathbf{b}$ were obtained from slow evaporation at r.t. of a solution in $\mathrm{CDCl}_{3}$ into a NMR tube.

7. Relative stability of the amidine complexes. i) $18.5 \mathrm{mg}$ of cis- $\left[\left(\mathrm{PPh}_{3}\right)_{2} \mathrm{Pt}(\mu-\mathrm{OH})\right]_{2}\left(\mathrm{NO}_{3}\right)_{2}\left(1.2 \times 10^{-2} \mathrm{mmol}\right)$ and $1-\mathrm{MeCy}$ $\left(3.0 \mathrm{mg}, 2.4 \times 10^{-2} \mathrm{mmol}\right)$ were rapidly dissolved in $0.8 \mathrm{~mL}$ of DMSO- $d_{6}$ solution containing equimolar amounts of $\mathrm{Me}_{3} \mathrm{CCN}$ (39 mg), $\mathrm{Ph}_{2} \mathrm{C}(\mathrm{H}) \mathrm{CN}\left(93 \mathrm{mg}\right.$ ) and $\mathrm{CH}_{3} \mathrm{CN}(20 \mathrm{mg}$ ) in order to have $\mathrm{Pt} /$ each nitrile ratio $1 / 20$. On the base of ${ }^{31} \mathrm{P} \mathrm{NMR}$ spectra, immediately after the dissolution $\mathbf{1 a}, \mathbf{1 c}$ and $\mathbf{1 d}$ were in a ratio of 9:0:1, after $24 \mathrm{~h}$ the corresponding ratio was $7: 1: 2$ and after 5 days at r.t. it became $2: 1: 7$. ii) $21.2 \mathrm{mg}$ of $c i s-\left[\left(\mathrm{PPh}_{3}\right)_{2} \operatorname{Pt}(\mu\right.$ $\mathrm{OH})]_{2}\left(\mathrm{NO}_{3}\right)_{2}\left(1.3 \times 10^{-2} \mathrm{mmol}\right)$ and $1-\mathrm{MeCy}\left(3.3 \mathrm{mg}, 2.6 \times 10^{-2}\right.$ mmol) were dissolved in a mixture of $0.3 \mathrm{~mL}$ of $\mathrm{CH}_{3} \mathrm{CN}$ and $0.3 \mathrm{~mL}$ of $\mathrm{PhCN}$ and the reaction was followed through ${ }^{31} \mathrm{P} \mathrm{NMR}$ with $\mathrm{D}_{2} \mathrm{O}$ as insert. Immediately after the dissolution the ratio between 1a:1b was $3: 2$ but after 5 days at room temperature only 1b was detectable.

\section{X-ray structure determination}

Crystal data and details of data collections and refinements for the structures reported are summarized in Table 1 . Intensity data of compounds $\mathbf{1 b}, \mathbf{3 b}$, and $\mathbf{5 b}$ were collected at room temperature (293(2) K) on a Nonius DIP-1030H system (Mo-K $\alpha$ radiation, $\lambda=$ $0.71073 \AA$ ), those of $\mathbf{6 b}$ on a Nonius FR591 rotating anode $(\mathrm{Cu}-$ $\mathrm{K} \alpha, \lambda=1.54178 \AA$ ), equipped with Kappa CCD imaging plate. Cell refinement, indexing and scaling for the data sets were performed by using Denzo and Scalepack programs. ${ }^{16}$ All the structures were solved by direct methods and subsequent Fourier analyses ${ }^{17}$ and refined by the full-matrix least-squares method based on $\mathrm{F}^{2}$ with all observed reflections. ${ }^{17} \mathrm{~A}$ molecule of diethylether was detected in the $\Delta \mathrm{F}$ map of $\mathbf{1 b}$. Hydrogen atoms were positioned at geometrical calculated positions except those of amine group in $\mathbf{3 b}, \mathbf{5 b}$, and $\mathbf{6 b}$. All the calculations were performed using the WinGX System, Ver $1.80 .05 .^{18}$

Crystallographic data for this paper is available in the ESI, CCDC numbers 811783-811786.†

\section{Results and discussion}

\section{Syntheses of the amidine complexes cis- $\left[\left(\mathrm{PPh}_{3}\right)_{2} \mathrm{PtNH}=\mathrm{C}(\mathrm{R})-\right.$ $\{$ nucleobase(-2H) $\}$ INO}

We have recently shown that the dinuclear hydroxo complex cis$\left[\left(\mathrm{PPh}_{3}\right)_{2} \mathrm{Pt}(\mu-\mathrm{OH})\right]_{2}\left(\mathrm{NO}_{3}\right)_{2}$ reacts with $1-\mathrm{MeCy}$ or $9-\mathrm{MeAd}$, in $\mathrm{CH}_{3} \mathrm{CN}$ or $\mathrm{PhCN}$, to give quantitatively the azametallacycles cis- $\left[\left(\mathrm{PPh}_{3}\right)_{2} \mathrm{PtNH}=\mathrm{C}(\mathrm{R})\{\right.$ nucleobase $\left.(-2 \mathrm{H})\}\right] \mathrm{NO}_{3}$, as depicted in Chart 1. By monitoring the reaction with ${ }^{31} \mathrm{P} \mathrm{NMR}$, it was

Table 1 Crystal data and details of structure refinements for compounds $\mathbf{1 b}, \mathbf{3 b}, \mathbf{5 b}$, and $\mathbf{6 b}$

\begin{tabular}{|c|c|c|c|c|}
\hline & $\mathbf{1 b} \cdot \mathrm{OEt}_{2}$ & $3 \mathbf{b}$ & $5 \mathbf{b}$ & $\mathbf{6 b}$ \\
\hline Formula weight & 1083.01 & 291.27 & 228.26 & 252.29 \\
\hline Space group & $P \overline{1}$ & $P 2_{1} / \mathrm{n}$ & $P 2_{1} / \mathrm{n}$ & $P \overline{1}$ \\
\hline$a(\AA)$ & $12.795(2)$ & $10.426(2)$ & $7.374(2)$ & $10.681(2)$ \\
\hline$b(\AA)$ & $14.002(2)$ & $9.226(2)$ & $11.022(3)$ & $10.645(3)$ \\
\hline$c(\AA)$ & $14.667(3)$ & $14.336(3)$ & $13.990(3)$ & $12.011(3)$ \\
\hline$\gamma\left({ }^{\circ}\right)$ & $95.843(10)$ & & & $95.54(2)$ \\
\hline Volume $\left(\AA^{3}\right)$ & $2351.9(7)$ & $1375.6(5)$ & $1118.4(5)$ & $1266.7(5)$ \\
\hline$Z$ & 2 & 4 & 4 & 4 \\
\hline$D_{\mathrm{c}}\left(\mathrm{g} \mathrm{cm}^{-3}\right)$ & 1.529 & 1.406 & 1.356 & 1.323 \\
\hline$\mu \mathrm{Mo}-\mathrm{K} \alpha,\left(\mathrm{mm}^{-1}\right)^{b}$ & 3.105 & 0.109 & 0.092 & 0.699 \\
\hline$F(000)$ & 1092 & 608 & 480 & 528 \\
\hline$\theta_{\max }\left({ }^{\circ}\right)$ & 27.88 & 26.73 & 25.02 & 60.04 \\
\hline Parameters & 587 & 200 & 161 & 357 \\
\hline Goodness of fit $\left(F^{2}\right)$ & 0.949 & 1.085 & 0.866 & 0.961 \\
\hline$R_{1}(I>2 \sigma(I))^{a}$ & 0.0400 & 0.0621 & 0.0521 & 0.0507 \\
\hline $\mathrm{w} R_{2}{ }^{a}$ & 0.0943 & 0.1920 & 0.1156 & 0.1238 \\
\hline Residuals (e/ $\left.\AA^{3}\right)$ & $0.996,-0.541$ & $0.412,-0.261$ & $0.207,-0.164$ & $0.132,-0.167$ \\
\hline
\end{tabular}


shown that the formation of $c i s-\left[\left(\mathrm{PPh}_{3}\right)_{2} \mathrm{PtNH}=\mathrm{C}(\mathrm{R})\{1-\mathrm{MeCy}\right.$ $(-2 \mathrm{H})\}] \mathrm{NO}_{3}(\mathrm{R}=\mathrm{Me}, \mathbf{1 a} ; \mathrm{Ph}, \mathbf{1 b})$ occurs at ambient temperature and no intermediates are detectable. In contrast, 9-MeAd undergoes deprotonation, giving initially the chelated $-N^{6}, N^{7}$ adeninate complex cis-[( $\left.\left(\mathrm{PPh}_{3}\right)_{2} \mathrm{Pt}\left\{9-\mathrm{MeAd}(-\mathrm{H}), N^{6} N^{7}\right\}\right] \mathrm{NO}_{3},{ }^{19}$ which reacts with a solvent molecule only after several hours at room temperature, affording quantitatively the insertion products cis$\left[\left(\mathrm{PPh}_{3}\right)_{2} \mathrm{PtNH}=\mathrm{C}(\mathrm{R})\{9-\mathrm{MeAd}(-2 \mathrm{H})\}\right] \mathrm{NO}_{3},(\mathrm{R}=\mathrm{Me}, \mathbf{2 a} ; \mathrm{Ph}, \mathbf{2 b})$.

A similar reaction pattern is observed when the deprotonation of 1-MeCy occurs in solution of $\mathrm{CH}_{2} \mathrm{Cl}_{2}$ in the presence of the substituted acetonitriles $\mathrm{Me}_{3} \mathrm{CCN}$ or $\mathrm{Ph}_{2} \mathrm{C}(\mathrm{H}) \mathrm{CN}$ and the amidines cis- $\left[\left(\mathrm{PPh}_{3}\right)_{2} \mathrm{PtNH}=\mathrm{C}(\mathrm{R})\{1-\mathrm{MeCy}(-2 \mathrm{H})\}\right] \mathrm{NO}_{3} \quad\left[\mathrm{R}=\mathrm{Me}_{3} \mathrm{C}, \mathbf{1 c}\right.$; $\left.\mathrm{Ph}_{2}(\mathrm{H}) \mathrm{C}, \mathbf{1 d}\right]$ are formed in quantitative yield (by ${ }^{31} \mathrm{P} \mathrm{NMR}$ ). The products 1c and 1d have been isolated as pure compounds and characterized by multinuclear NMR spectroscopy in $\mathrm{CDCl}_{3}$ and DMSO- $d_{6}$. In both the solvents, the compounds exhibit features similar to those of the $\mathrm{CH}_{3} \mathrm{CN}$ and $\mathrm{PhCN}$ analogous (1a and 1b), as shown in Table $\mathrm{T} 1$ (ESI $\dagger$ ) where the ${ }^{31} \mathrm{P}$ and selected ${ }^{1} \mathrm{H}$ NMR in $\mathrm{CDCl}_{3}$ data are collected. As previously observed for 1a, complexes 1c and 1d in solution of DMSO- $d_{6}$ appear stable while in chlorinated solvents they slowly (a few days at $25{ }^{\circ} \mathrm{C}$ ) decompose to give the free nitrile and uncharacterized platinum complexes. The reaction is reversible as indicated by the immediate and quantitative formation of the amidine complexes $1 \mathbf{c}$ and $\mathbf{1 d}$ upon addition of an excess of $\mathrm{Me}_{3} \mathrm{CCN}$ or $\mathrm{Ph}_{2} \mathrm{C}(\mathrm{H}) \mathrm{CN}$, respectively. The relative thermodynamic stability of the amidinic complexes 1a-1b was investigated by reacting the hydroxo complex and 1-MeCy in mixture of $\mathrm{CH}_{3} \mathrm{CN}$ and $\mathrm{PhCN}$ (see experimental). $\mathbf{1 a}$ and $\mathbf{1 b}$ are rapidly formed in a molar ratio $c a .3: 2$ and the composition of the reaction mixture slowly changed, leading to the quantitative presence of $\mathbf{1 b}$ in few days at r.t. The effect of the stabilization due to the presence of phenyl rings in the nitrile molecule is confirmed in another experiment where it has been observed that, carrying out the condensation reaction in DMSO- $d_{6}$ with an equimolar mixture of $\mathrm{CH}_{3} \mathrm{CN}, \mathrm{Me}_{3} \mathrm{CCN}$ and $\mathrm{Ph}_{2} \mathrm{C}(\mathrm{H}) \mathrm{CN}$, the relative concentration of $1 \mathbf{a}, \mathbf{1 c}$ and $\mathbf{1 d}$, at the equilibrium (after 5 days at $25^{\circ} \mathrm{C}$ ) was $2: 1: 7$.

As previously seen for $\mathrm{CH}_{3} \mathrm{CN}$ and $\mathrm{PhCN}$, ,10 the reaction of cis- $\left[\left(\mathrm{PPh}_{3}\right)_{2} \mathrm{Pt}(\mu-\mathrm{OH})\right]_{2}\left(\mathrm{NO}_{3}\right)_{2}$ with 9-MeAd in $\mathrm{CH}_{2} \mathrm{Cl}_{2}$, in the presence of an excess of $\mathrm{Me}_{3} \mathrm{CCN}$ or $\mathrm{Ph}_{2} \mathrm{C}(\mathrm{H}) \mathrm{CN}$, rapidly affords the intermediate cis- $\left[\left(\mathrm{PPh}_{3}\right)_{2} \mathrm{Pt}\left\{9-\operatorname{MeAd}(-\mathrm{H}), N^{6} N^{7}\right\}\right]^{+},{ }^{19}$ which slowly reacts with the nitrile to give the amidines cis- $\left[\left(\mathrm{PPh}_{3}\right)_{2} \mathrm{PtNH}=\mathrm{C}(\mathrm{R})\{9-\mathrm{MeAd}(-2 \mathrm{H})\}\right] \mathrm{NO}_{3} \quad\left(\mathrm{R}=\mathrm{Me}_{3} \mathrm{C}, \mathbf{2}\right.$; $\left.\mathrm{Ph}_{2}(\mathrm{H}) \mathrm{C}, \mathbf{2 d}\right)$. However the insertion of the nitrile molecule into the Pt-N(6) bond is not quantitative, even in the presence of a large excess of nitrile. As an example, the ${ }^{31} \mathrm{P}$ NMR spectrum of a mixture of cis-[( $\left.\left(\mathrm{PPh}_{3}\right)_{2} \mathrm{Pt}(\mu-\mathrm{OH})\right]_{2}\left(\mathrm{NO}_{3}\right)_{2}, 9-\mathrm{MeAd}$ and $\mathrm{Ph}_{2} \mathrm{C}(\mathrm{H}) \mathrm{CN}$, in molar ratio $1: 2: 20$, is shown in Fig. $\mathrm{S} 1$ (ESI $\dagger$ ). The AB pattern detected in the fresh prepared solution (Fig. S1a, ESI $\dagger$ ), at $\delta 8.78$ $\left({ }^{1} J_{\mathrm{PPt}}=3860 \mathrm{~Hz}\right)$ and $6.16 \mathrm{ppm}\left({ }^{1} J_{\mathrm{PPt}}=3100 \mathrm{~Hz} ;{ }^{2} J_{\mathrm{PP}}=20 \mathrm{~Hz}\right)$, is attributable to the $N^{6}, N^{7}$-chelated adeninate complex, and its relative concentration is about $40 \%$ after 8 days (Fig. S1b, ESI†). These results reflect the relatively high thermodynamic stability of the five membered $N 6, N 7$-chelated adenine complex with respect to the amidine derivative $\mathbf{2 d}$. Although $\mathbf{2} \mathbf{c}$ and $\mathbf{2 d}$ were not isolated as pure compounds, their ${ }^{31} \mathrm{P}$ NMR in $\mathrm{CDCl}_{3}$ parameters are included in Table T1 (ESI $\dagger$ ). The chemical shift and coupling constant values for these compounds also suggest a structure similar to those of $\mathbf{2 a}$ and $\mathbf{2 b}$, previously characterized. ${ }^{9,10}$
Syntheses and characterization of the amidines $\left[\mathrm{NH}_{2}=\mathbf{C}(\mathrm{R})\right.$ $\{$ nucleobase $(-\mathrm{H})\} \mid \mathrm{NO}_{3}$ and $\mathrm{NH}_{2}-\mathrm{C}(\mathrm{R})\{$ nucleobase $(-2 \mathrm{H})\}$

Addition of two equivalents of aqueous $\mathrm{HCl}$ to $\mathrm{CH}_{2} \mathrm{Cl}_{2}$ solutions of 1a,b and 2a,b leads to the immediate and quantitative protonation of the amidine ligands, released as nitrate salts $\left[\mathrm{NH}_{2}=\mathrm{C}(\mathrm{R})\{\right.$ nucleobase $\left.(-\mathrm{H})\}\right] \mathrm{NO}_{3}$ (nucleobase: 1-MeCy, $\mathrm{R}=$ $\mathrm{Me}, \mathbf{3 a} ; \mathrm{Ph}, \mathbf{3 b} ; 9$-MeAd, $\mathrm{R}=\mathrm{Me}, \mathbf{4 a} ; \mathrm{Ph}, \mathbf{4 b})$, and the concomitant coordination of the chloride ions to the metal centre (Chart 2). The platinum containing product, cis- $\left(\mathrm{PPh}_{3}\right)_{2} \mathrm{PtCl}_{2}$, dissolved in the chlorinated solvent, can be quantitatively separated from the reaction mixture.

All these organic compounds are insoluble in chlorinated solvents whereas they easily dissolve in $\mathrm{H}_{2} \mathrm{O}$, DMSO and DMF. Compounds $3 \mathbf{a}$ and $\mathbf{4 a}$, unlike the benzonitrile derivatives $\mathbf{3 b}$ and $\mathbf{4 b}$, slowly decompose in water (a few days, at room temperature) with formation of $\mathrm{CH}_{3} \mathrm{CN}$ and of the protonated nucleobases $[1-\mathrm{MeCyH}] \mathrm{NO}_{3}$ and $[9-\mathrm{MeAdH}] \mathrm{NO}_{3}$. Therefore, only $\mathbf{3 b}$ and $\mathbf{4 b}$ have been further characterized as neutral species, according to Chart 2.

Aqueous solutions of $\mathbf{3 b}$ and $\mathbf{4 b}$, upon addition of stoichiometric amounts of $\mathrm{NaOH}$, afford white precipitates of the neutral amidines $\mathrm{NH}_{2}-\mathrm{C}(\mathrm{Ph})\{1-\mathrm{MeCy}(-2 \mathrm{H})\} \quad(\mathbf{5 b})$ and $\mathrm{NH}_{2}-\mathrm{C}(\mathrm{Ph})\{9-$ $\operatorname{MeAd}(-2 \mathrm{H})\}(\mathbf{6 b})$ which have been characterized in solution by multinuclear NMR spectroscopy and in the solid state by single crystal X-ray analysis. These neutral species, insoluble in $\mathrm{H}_{2} \mathrm{O}$, dissolve in $\mathrm{CDCl}_{3}$ and DMSO- $d_{6}$, where they appear indefinitely stable. The ${ }^{1} \mathrm{H}$ NMR spectra of $\mathbf{5 b}$ and $\mathbf{6} \mathbf{b}$ exhibit well-resolved doublets for the cytosine $\mathrm{H} 5$ and $\mathrm{H} 6$ protons and very sharp singlets for $\mathrm{H} 2$ and $\mathrm{H} 8$ adenine signals. The $\mathrm{NH}$ resonances are observed as two broad singlets having the same relative intensities, with very different chemical shift values $(\Delta \delta 4.4$ and $5.1 \mathrm{ppm}$ for $\mathbf{5 b}$ and $\mathbf{6} \mathbf{b}$, respectively, in $\left.\mathrm{CDCl}_{3}\right) .{ }^{1} \mathrm{H},{ }^{15} \mathrm{~N}$ HMQC experiments (Fig. S2, ESI $\dagger$ ) of $\mathbf{5 b}$ indicate that both the $\mathrm{NH}$ signals at $\delta 11.56$ and $7.14 \mathrm{ppm}$ correlate with the same ${ }^{15} \mathrm{~N}$ nucleus (at $\delta-266 \mathrm{ppm}$ ), in agreement with the presence of two hydrogen atoms bound to the same nitrogen. Of the two possible tautomers of these amidines (Chart 2), the amino form appears to be the only one detectable in solution, as predicted by Prevorsek. ${ }^{20}$ The large chemical shift difference for the $\mathrm{NH}_{2}$ protons can be accounted for by the presence of relatively strong intermolecular hydrogen bonds, as detected in the solid state structure of $\mathbf{5 b}$ and $\mathbf{6 b}$ and discussed in the next section (Fig. S3 and S4, ESI $\dagger$ ).

A more complex ${ }^{1} \mathrm{H}$ NMR pattern was observed in the case of the protonated amidine $\mathbf{3 b}$. In fact, whereas in $\mathrm{D}_{2} \mathrm{O}$ the endocyclic protons $\mathrm{H}(6)$ and $\mathrm{H}(5)$ are observed as sharp doublets, with ${ }^{3} J_{\mathrm{HH}}=7.07 \mathrm{~Hz}$, they occur as poorly resolved doublets in DMSO- $d_{6}$. This unprecedented behaviour prompted us to study the system in DMF- $d_{7}$ at variable temperature. In this medium, at $25{ }^{\circ} \mathrm{C}, \mathrm{H} 5$ and $\mathrm{H} 6$ show very broad singlets at 7.4 and $9.0 \mathrm{ppm}$, respectively, and a sharp singlet at $3.57 \mathrm{ppm}$ for the $\mathrm{N}(1)$ methyl group. The $\mathrm{NH}$ proton resonances, undetectable in $\mathrm{D}_{2} \mathrm{O}$, are observed as very broad singlets, with the same relative intensities, at $13.4,12.9$ and $12.6 \mathrm{ppm}$ in DMF- $d_{7}$. Decreasing the temperature to $-55^{\circ} \mathrm{C}$, a sharpening of all the $\mathrm{NH}$ resonances is observed, with the concomitant progressive merging of those at higher field, to give a single resonance at $13.8 \mathrm{ppm}$, as shown in Fig. 1. A similar trend with the temperature is observed for 


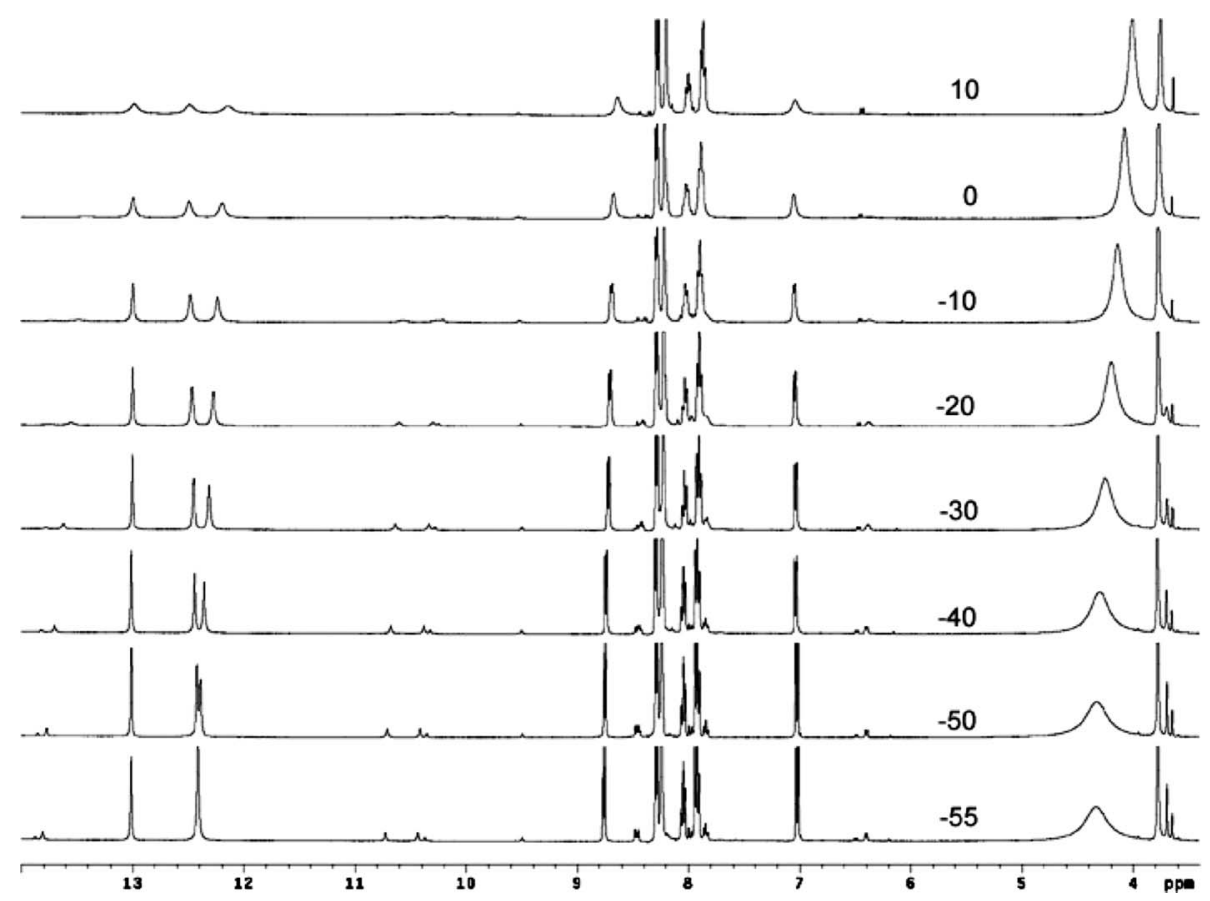

Fig. 1 Temperature dependence of the equilibrium between the monomer $\mathbf{3 b}$ and the dimer $\mathbf{3} \mathbf{b}^{\prime}$ in DMF- $d_{7}$. Only selected temperatures are shown.

the H5 and H6 signals, which become sharp doublets at low temperature.

\section{NMR investigation of the H-bonded monomer-dimer equilibrium of $3 b$}

Inspection of Fig. 5 reveals in $\mathbf{3 b}$ the presence of dimeric species formed via $\mathrm{H}$-bonding between the iminium protons at $\mathrm{N} 2$ and the carbonylic oxygen $\mathrm{O} 2$. In addition, the aminic proton $\mathrm{N} 4$ and one nitrate oxygen are at $\mathrm{H}$-bonding distance. These features are almost exactly reproduced in solution of DMF- $d_{7}$, as revealed by the ${ }^{1} \mathrm{H}$ NMR spectra monitored at different temperatures (Fig. 1). The dynamic behaviour in solution discloses other relevant features.

In the ${ }^{1} \mathrm{H}$ NMR spectrum recorded at $-50{ }^{\circ} \mathrm{C}$, three major broad peaks are observed between 12.2 and $13.2 \mathrm{ppm}$, i.e. within the typical $\mathrm{H}$-bonding resonance range, beside three minor peaks: one in the H-bonding resonance range $(\delta=13.8 \mathrm{ppm})$, the last two are somehow more shielded $(\delta=10.75$ and $10.42 \mathrm{ppm})$. These are NH resonances which can be accounted for due to the dimermonomer equilibrium illustrated in Chart 3.

On the basis of this scheme, two major resonances, in the $\mathrm{H}$ bond region and assigned to the $\mathrm{NH}$ protons of the iminium moiety, account for the formation of the dimer $\mathbf{3} \mathbf{b}^{\prime}$. The minor resonances in the more shielded region are again the $\mathrm{NH}$ resonances of the iminium moiety in the "free" monomer $\mathbf{3 b}$, and the last major and minor resonances in the $\mathrm{H}$-bond region pertain to the aminic proton of the dimer and of the monomer, respectively, that are $\mathrm{H}$-bonded to the nitrate anion. The presence of H-bonds in solution between aminic protons and inorganic anions is documented. ${ }^{21}$ This case is somehow different from the picture given by the X-ray diffraction analysis reported in Fig. 5, which highlights the presence of a dimer $\mathbf{3} \mathbf{b}^{\prime \prime}$ with only two different H-bond interactions: of the aminic proton with the nitrate anion, and of only one iminium proton with carbonylic oxygen. This may be a situation dictated by packing requirements of the crystalline state.

The presence of the three major resonances in the H-bond region may be accounted for due to the dimeric structure of $\mathbf{3} \mathbf{b}^{\prime}$. Alternatively, the equilibrium, fast at room temperature, between the dimeric strucure $\mathbf{3} \mathbf{b}^{\prime \prime}$ and $\mathbf{3} \mathbf{b}^{\prime \prime \prime}$ can be proposed. However, this situation would lead to an averaged $\mathrm{NH}$ resonance in a more shielded region. Thus the arrangement $\mathbf{3} \mathbf{b}^{\prime}$ that is to be preferred, would require the slow proton exchange between water (always present) and the aminium an iminium centers, and also the low rotation around the $\mathrm{CN}$ double bond.

At higher temperatures, the increasing exchange rates for the monomer-dimer equilibrium bring about the broadening and the final collapse of the NH resonances present in equivalent positions. This dynamic behaviour can be monitored and quantified in terms of equilibrium constants (see below) up to about $0{ }^{\circ} \mathrm{C}$; at higher temperatures contaminations by other phenomena (rotations and proton exchanges) will interfere.

The thermodynamic behaviour can be monitored from other resonances of the monomer-dimer system, which therefore must be exactly attributed. Proton 5 and 6 of the 2-oxopyrimidine ring are in the form of doublets, in both structures, and therefore easily recognized, but not singularly assigned. The attribution procedure occurs via a NOESY experiment that at $-55^{\circ} \mathrm{C}$ is ambiguous: both the monomer and the dimer are in the "negative" NOE region, and the dipolar interactions are indistinguishable from exchange interactions. At $20^{\circ} \mathrm{C}$ the resonances of the 2-oxopyrimidine ring collapse into two broad singlets. In the NOESY spectrum in Fig. S5 (ESI $\dagger$ ), the deshielded singlet at $8.60 \mathrm{ppm}$ belonging to proton 6 gives dipolar interaction with the methyl signal at $3.75 \mathrm{ppm}$. The shielded singlet at $7.02 \mathrm{ppm}$ gives a dipolar interaction with the 


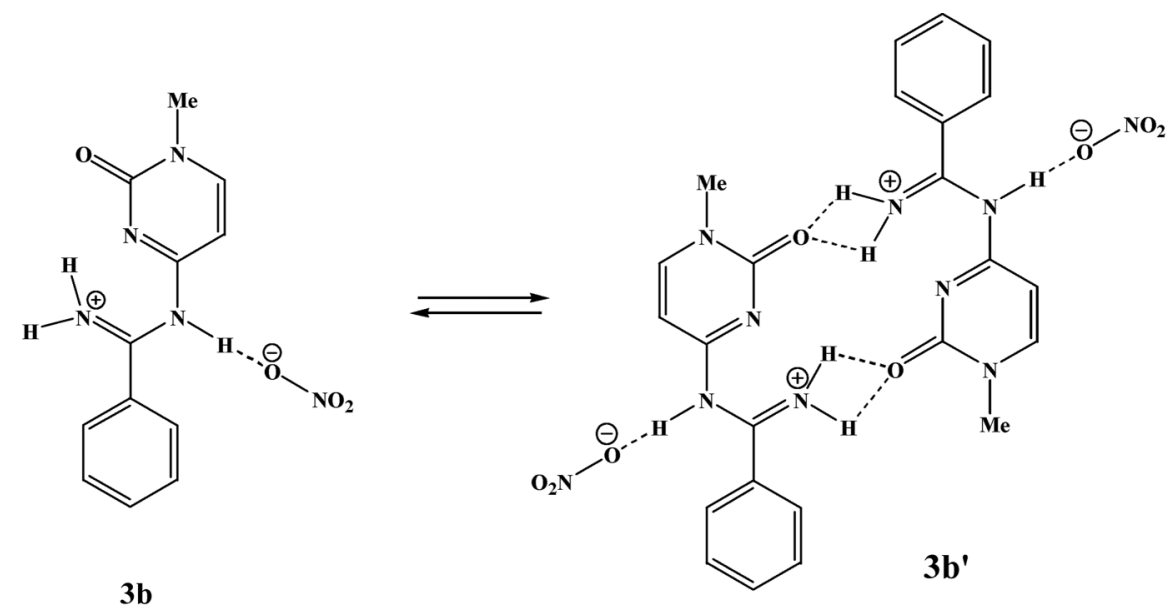

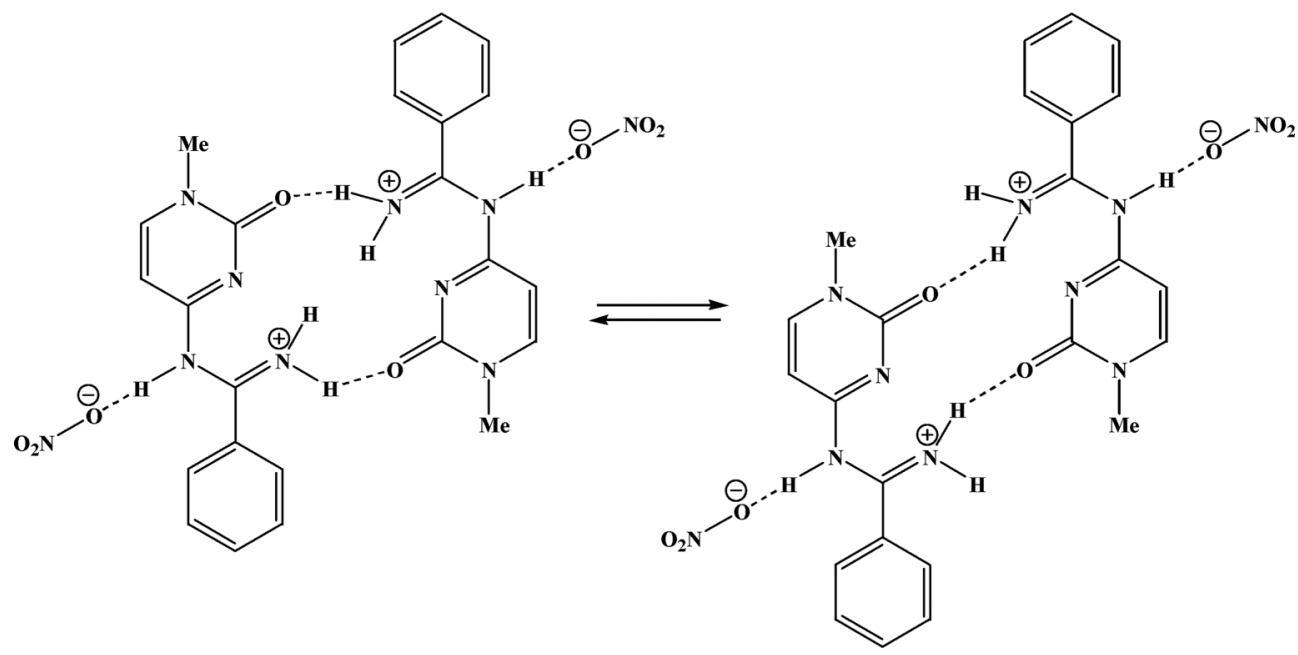

Chart 3 Dimer-monomer equilibrium of $\mathbf{3 b}$.

intense water signal at $3.95 \mathrm{ppm}$, denouncing the proximity to the aminic proton (which exchanges fast with water protons): this is the signal of proton 5 (See Fig. S5, ESI $\dagger$ ).

At low temperatures, the resonances of protons 5 and 6 split into two pairs of doublets. The doublets of protons 6 resonate in a free region and will be utilized for a quantitative evaluation of the thermodynamics via the van'Hoff analysis of the monomer-dimer interconversion.

\section{Van't Hoff plot}

The integration of NMR peaks is, among the NMR parameters, the one measured with the least accuracy, also because of the limits of the instrumental numeric procedure. We therefore adopted the strategy of fitting the peaks into a combination of Gaussian and Lorentzian functions, followed by the analytical integration of these. The fitting is computationally accomplished with the Levenberg-Marquardt method. ${ }^{22}$ Accurate integration values can be acquired between -55 and $15^{\circ} \mathrm{C}$, i.e. just below the coalescence temperature. The equilibrium constant $\mathrm{K}$ for the process is defined by:

$$
2 \text { monomer } \mathbf{3 b} \underset{\mathrm{bdm}}{\stackrel{\mathrm{Kmd}}{\rightleftarrows}} \operatorname{dimer} \mathbf{3} \mathbf{b}^{\prime}
$$

where $\mathrm{K}=\frac{\left[\text { dimer } \mathbf{3} \mathbf{b}^{\prime}\right]}{[\text { monomer } \mathbf{3 b}]^{2}}$ and $2\left[\right.$ dimer $\left.\mathbf{3} \mathbf{b}^{\prime}\right]+[$ monomer $\mathbf{3 b}]=$ $0.011 \mathrm{~mol} \mathrm{~L}^{-1}$

This is a non-equimolar equilibrium, and therefore the concentration of $\mathbf{3 b}$ in DMF- $d_{7}$ must be determined with utmost accuracy, more for a correct evaluation of the equilibrium entropy $\Delta S^{\circ}$ than for the evaluation of the equilibrium enthalpy $\Delta H^{\circ}$. The monomer $\mathbf{3 b}$ and DMF- $d_{7}$ were weighed in the NMR tube, and the concentration was checked after the measurement session by the further addition of a weighed amount of a substance with relevant molecular weight and one small $1 \mathrm{H}$ peak resonating in a free region: the choice was triethyl orthoformate.

From the Van't Hoff plot, the thermodynamic parameters $\Delta H^{\circ}=-1.58 \mathrm{kcal} \mathrm{L} \mathrm{mol}^{-1}$ and $\Delta S^{\circ}=9.01 \mathrm{cal} \mathrm{K}^{-1} \mathrm{~L} \mathrm{~mol}^{-1}$ are determined. 
The positive entropy change for a dimerization process is unexpected so we then verified the accuracy of the results with the analytical integration of other signals, the $\mathrm{NH}$ and the methyl resonances, retrieving very similar positive values. Some comments on this point are necessary. Positive entropy changes for dimerization processes promoted by intermolecular $\mathrm{H}$-bonding are not common, and are invariably associated with condensed phase experiments run in highly polar solvents. ${ }^{23} \mathrm{~A}$ rationalization has been offered. ${ }^{24}$ Since the molecular dipole vectors of two molecules such as $\mathbf{3 b}$ mutually cancel upon the formation of a H-bonded dimer, the latter species possesses no molecular dipole vector. Highly polar solvent molecules are heavily organized around the monomer with relevant dipole vector, but to a relevantly minor extent around a dimer lacking a molecular dipole vector.

\section{X-ray structural studies}

The X-ray structural determination of complex $\mathbf{1 b}$ shows the insertion of the benzonitrile molecule into the cytosine Pt-N(4) bond with formation of a six-membered ring, as depicted in Fig. 2. Selected bond distances and angles are collected in Table 2.

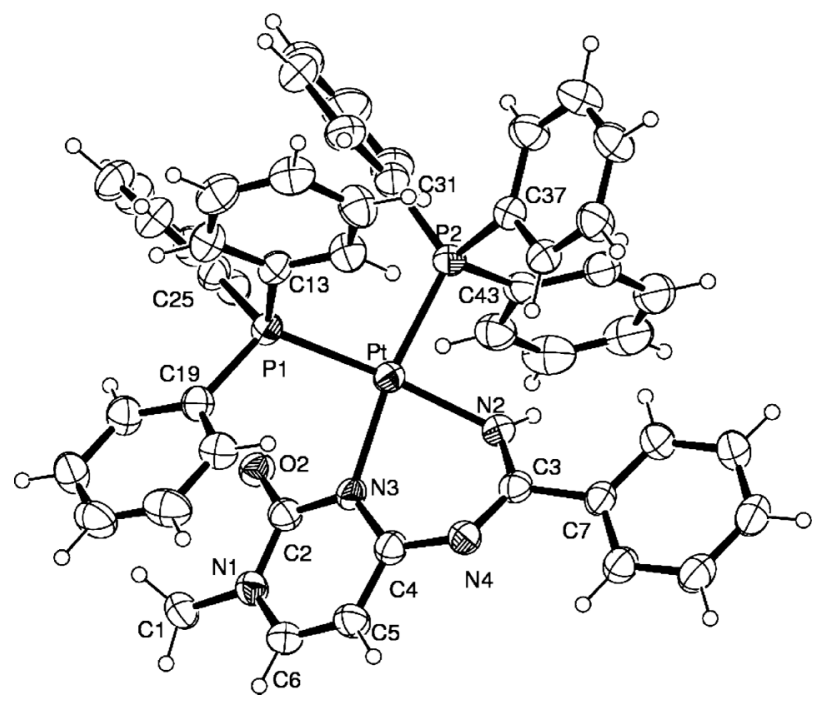

Fig. 2 ORTEP drawing ( $35 \%$ probability ellipsoids) of the cation of $\mathbf{1 b}$.

The platinum is bound to the nucleobase donor site N3, the inserted benzonitrile nitrogen $\mathrm{N} 2$, and completes the square planar coordination through phosphorus donors. The $\mathrm{Pt}-\mathrm{N} 3$ and $\mathrm{Pt}-\mathrm{N} 2$ bond distances are of 2.074(4) and 2.052(4) A. The former bond length appears slightly shorter, the other longer with respect to the values measured in complexes cis- $\left[\left(\mathrm{PMePh}_{2}\right)_{2} \mathrm{PtNH}=\mathrm{C}(\mathrm{R})\{1-\right.$ $\mathrm{MeCy}(-2 \mathrm{H})\}]^{+}$with $\mathrm{R}=\mathrm{Me}^{9}(2.097(4)$ and 2.036(4) $\AA$, respectively) and $\mathrm{Ph}^{10}(2.112(7)$ and 2.043(6) $\AA$ ). The Pt-P bond distances are 2.2955(12) and 2.2898(13) $\AA$. The $\mathrm{N}_{2} \mathrm{P}_{2}$ donors show a slight

Table 2 Selected bond lengths $(\AA)$ and angles $\left({ }^{\circ}\right)$ of $\mathbf{1 b}$

\begin{tabular}{llll}
\hline $\mathrm{Pt}-\mathrm{N}(2)$ & $2.052(4)$ & $\mathrm{Pt}-\mathrm{P}(1)$ & $2.2955(12)$ \\
$\mathrm{Pt}-\mathrm{N}(3)$ & $2.074(4)$ & $\mathrm{Pt}-\mathrm{P}(2)$ & $2.2898(13)$ \\
$\mathrm{N}(2)-\mathrm{Pt}-\mathrm{N}(3)$ & $82.20(14)$ & $\mathrm{N}(3)-\mathrm{Pt}-\mathrm{P}(1)$ & $92.35(10)$ \\
$\mathrm{N}(2)-\mathrm{Pt}-\mathrm{P}(1)$ & $165.21(12)$ & $\mathrm{N}(3)-\mathrm{Pt}-\mathrm{P}(2)$ & $166.67(11)$ \\
$\mathrm{N}(2)-\mathrm{Pt}-\mathrm{P}(2)$ & $88.48(11)$ & $\mathrm{P}(2)-\mathrm{Pt}-\mathrm{P}(1)$ & $98.92(5)$ \\
\hline
\end{tabular}

tetrahedral distortion in $\mathbf{1 b}$, with deviations up to $\pm 0.22 \AA$ from their mean plane. The amidine fragment results bowed with the cytosine and phenyl from the benzonitrile that formed an angle of $15.0(1)^{\circ}$, while the nucleobase ring forms a dihedral angle of $49.2(1)^{\circ}$ with the mean coordination plane $\mathrm{N}_{2} \mathrm{P}_{2}$. Inside the six-membered ring fragment, the geometrical parameters indicate an electron delocalization. The molecule shows a $\pi-\pi$ stacking between the cytosine and $\mathrm{PPh}_{3}$ phenyl ring $\mathrm{C}(19)$ and a slightly stronger interaction between the phenyl rings $\mathrm{C}(25)$ and $\mathrm{C}(31)$ of the two $\mathrm{PPh}_{3}$ (distance between ring centroids of 3.69 and $3.47 \AA$, dihedral angle 20.34 and $8.38^{\circ}$, respectively).

The molecular structures of the protonated and neutral benzimidamide $\left[\mathrm{NH}_{2}=\mathrm{C}(\mathrm{Ph})\{1-\mathrm{MeCy}(-\mathrm{H})\}\right] \mathrm{NO}_{3}(\mathbf{3 b})$ and $\mathrm{NH}_{2}-\mathrm{C}(\mathrm{Ph})\{1-$ $\mathrm{MeCy}(-2 \mathrm{H})\}(\mathbf{5 b})$ are depicted in Figs. 3 and 4 respectively. The

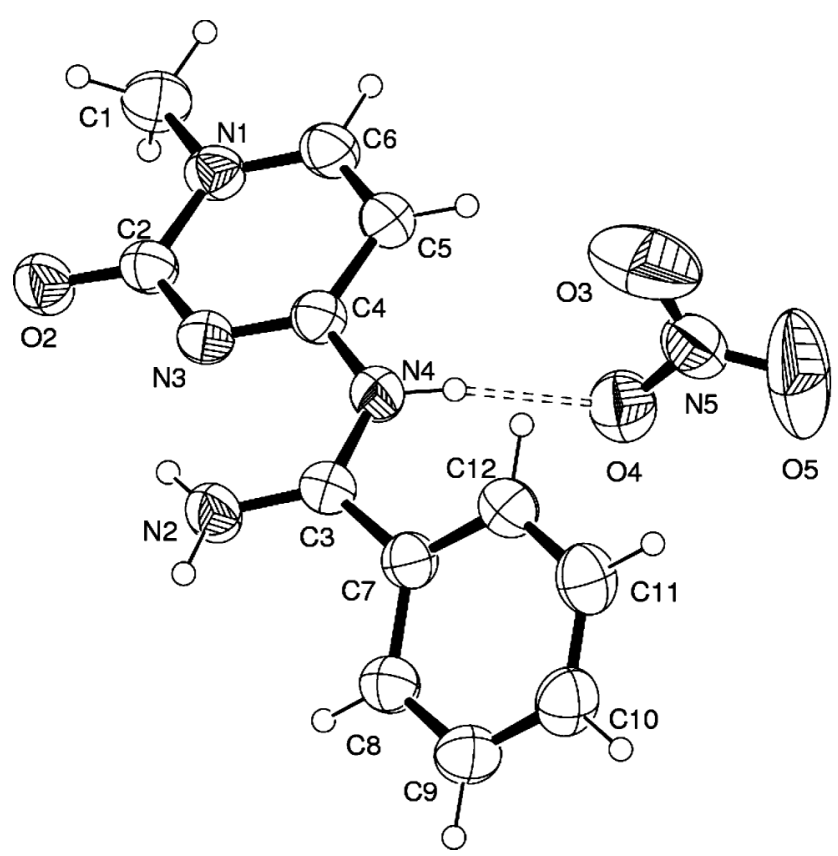

Fig. 3 ORTEP drawing (35\% probability ellipsoids) of compound $\mathbf{3 b}$.

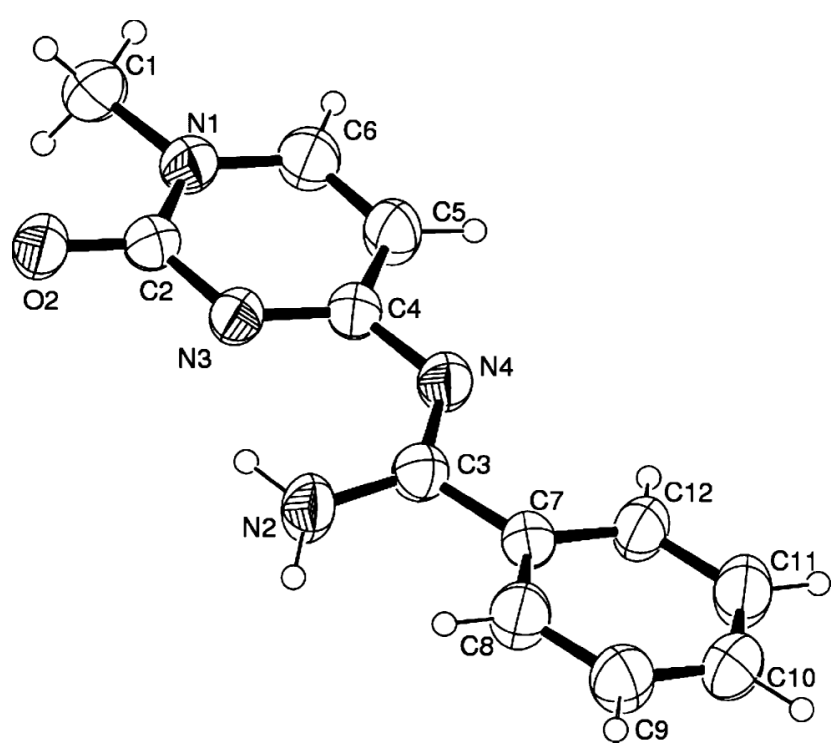

Fig. 4 ORTEP drawing (35\% probability ellipsoids) of compound $\mathbf{5 b}$ 
Table 3 Comparison of bond lengths ( $\AA$ ) and angles $\left({ }^{\circ}\right)$ of the amidine fragment in complexes cis-[( $\left.\mathrm{PMePh}_{2}\right)_{2} \mathrm{PtNH}=\mathrm{C}(\mathrm{Me})\{1-\mathrm{MeCy}$ $(-2 \mathrm{H})\}] \mathrm{NO}_{3}$ (5a in ref [9]), cis-[(PMePh$)_{2} \mathrm{PtNH}=\mathrm{C}(\mathrm{Ph})\{1-\mathrm{MeCy}(-$ $2 \mathrm{H})\}] \mathrm{NO}_{3}(2 \mathrm{ref}[10]), \mathbf{1 b}$ and in the free ligands $\mathbf{3 b}$ and $\mathbf{5 b}$

\begin{tabular}{llllll}
\hline & $\underline{5} a \operatorname{ref}[9]$ & $\underline{2} \operatorname{ref}[10]$ & $\mathbf{1 b}$ & $\mathbf{3 b}$ & $\mathbf{5 b}$ \\
\hline $\mathrm{N}(3)-\mathrm{C}(4)$ & $1.358(7)$ & $1.339(10)$ & $1.347(6)$ & $1.306(3)$ & $1.329(4)$ \\
$\mathrm{C}(4)-\mathrm{N}(4)$ & $1.356(7)$ & $1.342(10)$ & $1.351(6)$ & $1.399(3)$ & $1.372(4)$ \\
$\mathrm{N}(4)-\mathrm{C}(3)$ & $1.337(7)$ & $1.302(10)$ & $1.342(6)$ & $1.361(3)$ & $1.316(4)$ \\
$\mathrm{C}(3)-\mathrm{N}(2)$ & $1.295(7)$ & $1.327(10)$ & $1.312(6)$ & $1.291(3)$ & $1.325(4)$ \\
$\mathrm{C}(3)-\mathrm{C}(7)$ & $1.503(8)$ & $1.488(10)$ & $1.507(6)$ & $1.472(3)$ & $1.482(4)$ \\
$\mathrm{C}(3)-\mathrm{N}(4)-\mathrm{C}(4)$ & $122.6(5)$ & $122.8(8)$ & $121.1(4)$ & $127.54(17)$ & $122.8(3)$ \\
$\mathrm{N}(3)-\mathrm{C}(4)-\mathrm{N}(4)$ & $125.6(5)$ & $127.5(9)$ & $124.9(5)$ & $119.14(17)$ & $122.8(3)$ \\
$\mathrm{N}(4)-\mathrm{C}(3)-\mathrm{N}(2)$ & $126.7(5)$ & $126.7(8)$ & $126.6(4)$ & $121.46(19)$ & $125.5(3)$ \\
\hline
\end{tabular}

geometrical parameters of the amidine moiety for these species are reported in Table 3 together with the corresponding values measured in complexes $\mathbf{1 b}$ and cis- $\left[\left(\mathrm{PMePh}_{2}\right)_{2} \mathrm{PtNH}=\mathrm{C}(\mathrm{R})\{1-\right.$ $\operatorname{MeCy}(-2 \mathrm{H})\}]^{+}\left(\mathrm{R}=\mathrm{Me}^{9}\right.$ and $\left.\mathrm{Ph}^{10}\right)$. The protonated amidine 3b shows the most striking differences: in particular in the fragment $\mathrm{N}(2)-\mathrm{C}(3)-\mathrm{N}(4)-\mathrm{C}(4)$ where the former bond distance is shorter (1.291(3) $\AA$ ) and the other longer (1.361(3), 1.399(3) $\AA$, respectively) with regard to the values found in the metal complexes and in $\mathbf{5 b}$. Correspondingly, the angle $\mathrm{C}(3)-\mathrm{N}(4)-\mathrm{C}(4)$ of $127.54(17)^{\circ}$ is the largest among those reported for the presence of the proton on $\mathrm{N}(4)$ which acts as a $\mathrm{H}$ donor towards the nitrate. In addition, the bond angles $\mathrm{N}(3)-\mathrm{C}(4)-\mathrm{N}(4)$ appear narrower (119.14(17) and $122.8(3)^{\circ}$ in $\mathbf{3 b}$ and $\mathbf{5 b}$, respectively, than the values observed in the complexes. The phenyl ring is tilted by $29.86(5)$ and $7.1(2)^{\circ}$ in amidine molecules $\mathbf{3 b}$ and $\mathbf{5 b}$, respectively. A more interesting observation is that the dihedral angle formed by the cytosine ring with the $\mathrm{C} 7 / \mathrm{C} 3 / \mathrm{N} 2 / \mathrm{N} 4$ moiety, of $c a .9^{\circ}$ in both, while upon coordination the measured value observed in $\mathbf{1 b}$ is $25.7(1)^{\circ}$. In the crystal the molecular cations of $\mathbf{3 b}$ are paired through $\mathrm{H}$-bond interactions, beside the $\mathrm{N} 4-\mathrm{H} \cdots \mathrm{O} 2$ interaction cited above (Fig. 5)

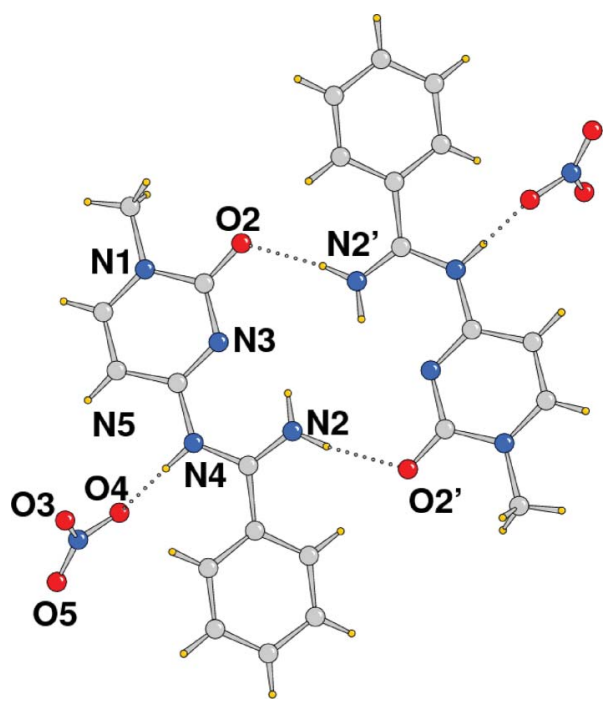

Fig. 5 Crystal packing of $\mathbf{3 b}$ showing the dimers formed through $\mathrm{H}$-bond interactions, (primed atoms at 2-x, 1-y, 1-z).

The structural analysis of $\mathbf{6 b}$ shows the presence in the unit cell of two independent molecules (Fig. 6) which are very similar as far as their geometry is concerned. These molecules form a

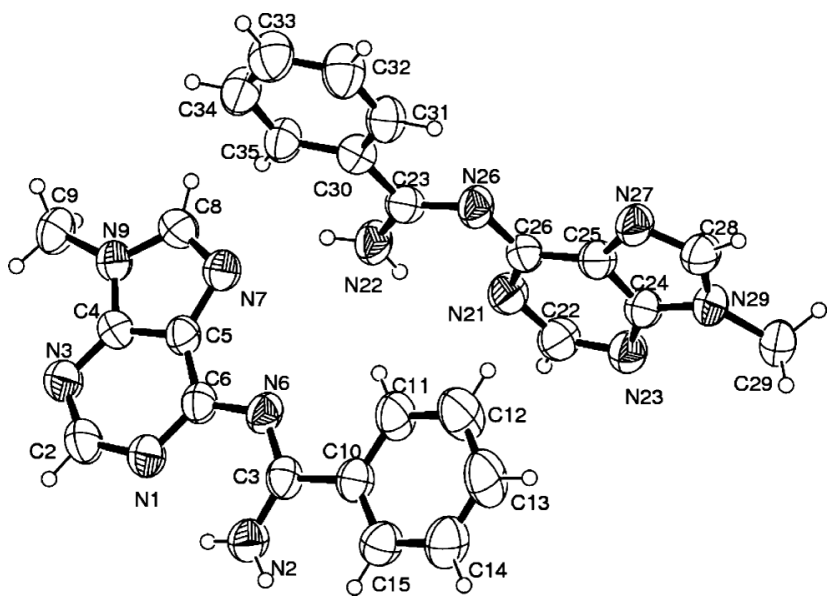

Fig. 6 ORTEP drawing (35\% probability ellipsoids) of the two independent molecules of $\mathbf{6 b}$.

polymeric arrangement being alternatively connected along axis $b$ by $\mathrm{H}$ bonds involving the amino group $\mathrm{N} 2$ and the endocyclic nitrogen $\mathrm{N} 7$ of the adjacent adenine moiety $(\mathrm{N} \cdots \mathrm{N}$ distance of ca. $2.97 \AA$ ), as depicted in Fig. S3 (ESI $\dagger$ ). In Table T2 (ESI $\dagger$ ) we report a comparison of the geometrical parameters of the two molecules A and B with the data obtained from the Pt complex $\mathbf{2 b}$ and of complexes containing the amidine ligand derived from the acetonitrile.

These data clearly show a shortening of the $\mathrm{C}(3)-\mathrm{N}(2)$ bond distance upon coordination (range 1.279(11)-1.295(8) ^ vs. 1.324(5) and 1.334(4) $\AA$ in the free amidines), with a concurrent widening of the $\mathrm{N}(1)-\mathrm{C}(6)-\mathrm{N}(6)$ angle (mean values of $127.4^{\circ}$ vs. $123.3^{\circ}$, respectively). Moreover the $\mathrm{C}(6)-\mathrm{N}(6)$ bond distances in the free molecules $\mathrm{A}$ and $\mathrm{B}$ appear elongated with respect to the value measured upon coordination.

Here, and in the corresponding analysis of the amidine ligand built from the cystosine base (Table 3), it is not straightforward to derive a clear trend between the free and the coordinated species. Making allowance for e.s.d.'s of the geometrical data, this may be ascribed to the electron delocalization in the molecules, to the $\mathrm{H}$ bonding scheme observed among the free benzimidamides in the solid state, but also to the deformations assumed by the chelating amidine-nucleobase fragment in the complex (likely to accomplish steric requirements) with respect to the planar arrangement found in the free molecules.

\section{Coordination properties of the neutral amidines $\mathrm{NH}_{2}-\mathrm{C}(\mathrm{Ph})-$ $\{$ nucleobase $(-2 \mathrm{H})\}$}

The data so far reported for the neutral amidines $\mathbf{5 b}$ and $\mathbf{6 b}$ clearly support the presence in the solid and in solution of the amino tautomer (Chart 2). The stabilization of the imino form likely occurs when these molecules react with the complex cis$\left(\mathrm{PPh}_{3}\right)_{2} \mathrm{Pt}\left(\mathrm{ONO}_{2}\right)_{2} \cdot{ }^{12} \mathrm{In}$ fact, addition of stoichiometric amounts of $\mathbf{5 b}$ or $\mathbf{6 b}$ to a colourless solution of the nitrato complex causes the immediate appearance of a pale yellow colour attributable to the replacement of the nitrato ligands in the coordination sphere of the metal and the concomitant formation of the adducts cis- $\left[\left(\mathrm{PPh}_{3}\right)_{2} \mathrm{PtNH}=\mathrm{C}(\mathrm{Ph})\{\text { nucleobase }(-\mathrm{H})\}\right]^{2+}$, depicted in Chart 2 for the $\mathrm{NH}=\mathrm{C}(\mathrm{Ph})\{1-\mathrm{MeCy}(-\mathrm{H})\}$ derivative. Thus, the reaction of $\mathbf{5 b}$ with cis- $\left(\mathrm{PPh}_{3}\right)_{2} \mathrm{Pt}\left(\mathrm{ONO}_{2}\right)_{2}$, in $\mathrm{CDCl}_{3}$, causes the immediate 
change of the ${ }^{31} \mathrm{P}$ NMR spectrum, shown in Fig. 7, in which the singlet at $\delta 3.50\left({ }^{1} J_{\mathrm{PPt}}=4018 \mathrm{~Hz}\right)$ of the nitrato complex is completely replaced by an $\mathrm{AB}$ multiplet at $4.80\left({ }^{1} J_{\mathrm{PPt}}=3504\right.$ $\mathrm{Hz})$ and $6.58 \mathrm{ppm}\left({ }^{1} J_{\mathrm{PPt}}=3543 ;{ }^{2} J_{\mathrm{PP}}=25.1 \mathrm{~Hz}\right)$, attributable to the adduct cis- $\left[\left(\mathrm{PPh}_{3}\right)_{2} \mathrm{PtNH}=\mathrm{C}(\mathrm{Ph})\{1-\mathrm{MeCy}(-\mathrm{H})\}\right]^{2+}$ (7b). The values of coupling constants ${ }^{31} \mathrm{P}-{ }^{195} \mathrm{Pt}$, slightly increased (an average of $72 \mathrm{~Hz}$ ) with respect to those of the strictly related species $c i s-\left[\left(\mathrm{PPh}_{3}\right)_{2} \mathrm{PtNH}=\mathrm{C}(\mathrm{Ph})\{1-\mathrm{MeCy}(-2 \mathrm{H})\}\right]^{+}(\mathbf{1 b})$, strongly support the presence in 7 of the neutral amidine acting as a $N, N$ chelating ligand.

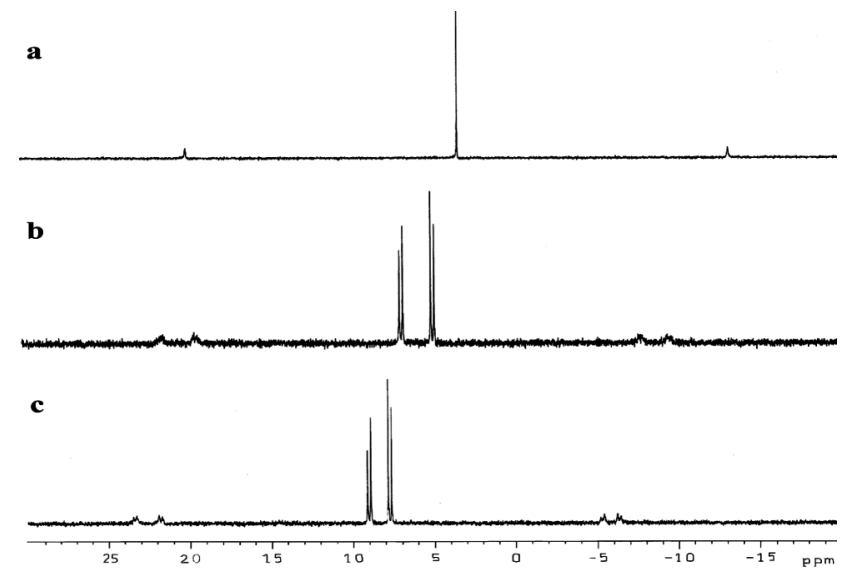

Fig. $7{ }^{31} \mathrm{P}\left\{{ }^{1} \mathrm{H}\right\} \mathrm{NMR}$ spectra in $\mathrm{CDCl}_{3}$ of: a) cis- $\left(\mathrm{PPh}_{3}\right)_{2} \mathrm{Pt}\left(\mathrm{ONO}_{2}\right)_{2}$; b) after addition of $\left.\mathrm{NH}_{2}-\mathrm{C}(\mathrm{Ph})\{1-\mathrm{MeCy}(-2 \mathrm{H})\}, \mathbf{5 b} ; c\right)$ after addition of "proton sponge".

Moreover, addition of "proton sponge" to the $\mathrm{CDCl}_{3}$ solution of $\mathbf{7 b}$ causes the immediate deprotonation of the imino ligand, with the quantitative formation of complex $\mathbf{1 b}$, as shown in Fig. 7c. In the same experimental conditions, a more complex ${ }^{31} \mathrm{P}$ NMR spectrum was observed when $6 \mathbf{b}$ was reacted with cis- $\left(\mathrm{PPh}_{3}\right)_{2} \mathrm{Pt}\left(\mathrm{ONO}_{2}\right)_{2}$. In addition to the strong $\mathrm{AB}$ pattern at $7.73\left({ }^{1} J_{\mathrm{PPt}}=3467 \mathrm{~Hz}\right)$ and $8.01 \mathrm{ppm}\left({ }^{1} J_{\mathrm{PPt}}=3413 ;{ }^{2} J_{\mathrm{PP}}=\right.$ $24.5 \mathrm{~Hz})$, attributed to the adduct cis- $\left[\left(\mathrm{PPh}_{3}\right)_{2} \mathrm{Pt} \mathrm{NH}=\mathrm{C}(\mathrm{Ph})\{9-\right.$ $\operatorname{MeAd}(-\mathrm{H})\}]^{2+}(\mathbf{8 b})$, several weak signals in the range 4-16 ppm were also detected. However, addition of a "proton sponge" caused the immediate disappearance of all these signals, quantitatively replaced by those of the $\mathrm{AB}$ multiplet of $c i s-\left[\left(\mathrm{PPh}_{3}\right)_{2} \mathrm{Pt}\right.$ $\mathrm{NH}=\mathrm{C}(\mathrm{Ph})\{9-\mathrm{MeAd}(-2 \mathrm{H})\}]^{+}, \mathbf{2 b}$. We are currently trying to crystallize complexes $\mathbf{7 b}$ and $\mathbf{8 b}$ for a complete characterization in solution and in the solid state. It is interesting to note that the related species $\mathbf{2 a}, \mathbf{b}$ together with the analogs 1a,b exhibit interesting cytotoxic properties toward several human tumour cell lines. $^{25}$

\section{Conclusions}

The synthesis and structural characterization of the substituted amidines (Z)- $N$-(1-methyl-2-oxo-1,2-dihydropyramidin4-yl)benzimidamide (5b) and (Z)- $N^{\prime}$-(9-methyl-9H-purin-6yl)benzimidamide (6b) and their nitrato salts $\mathbf{3 b}$ and $\mathbf{4 b}$, are described. The compounds are formed by protonation with $\mathrm{HCl}$ of the metallacycles $c i s-\left[\left(\mathrm{PPh}_{3}\right)_{2} \mathrm{PtNH}=\mathrm{C}(\mathrm{Ph})\right.$ \{nucleobase($2 \mathrm{H})\}]^{+}$, which are quantitatively obtained by formal insertion of a molecule of $\mathrm{PhCN}$ molecule into the $\mathrm{Pt}-\mathrm{N}(4)$ or $\mathrm{Pt}-\mathrm{N}(6)$ bond of a platinum-cytosine or adenine complex, respectively. The high affinity of the chloride ions toward the $\mathrm{Pt}(\mathrm{II})$ centre, with formation of cis- $\left(\mathrm{PPh}_{3}\right)_{2} \mathrm{PtCl}_{2}$, allows the quantitative recovery of the metal. The planar structure of $\mathbf{3 b}$ in the solid state is stabilized by a strong $\mathrm{H}$-bond between the $\mathrm{NO}_{3}{ }^{-}$ion and the hydrogen atom on $\mathrm{N}(4)$ cytosine, whereas intermolecular $\mathrm{H}$-bonds between the oxygen of the cytosine ring and one of the $\mathrm{H}$ atoms of the amidine- $\mathrm{NH}_{2}$ group lead to the dimerization of the molecule. The analysis of the proton spectrum of $\mathbf{3 b}$ in DMF- $d_{7}$ shows the presence of an equilibrium between the monomer and the dimer, both exchanging with trace amounts of water, at room temperature.

In addition to $\mathrm{MeCN}$ and $\mathrm{PhCN}$, the nucleophylic attack of the $\mathrm{NH}_{2}$-deprotonated nucleobase occurs to the metal-activated nitriles $\mathrm{Me}_{3} \mathrm{CCN}$ and $\mathrm{Ph}_{2} \mathrm{C}(\mathrm{H}) \mathrm{CN}$ to give the amidine complexes cis- $\left[\left(\mathrm{PPh}_{3}\right)_{2} \mathrm{PtNH}=\mathrm{C}(\mathrm{R})\{\right.$ nucleobase $\left.(-2 \mathrm{H})\}\right] \mathrm{NO}_{3}$, isolated in high yield for the 1-methylcytosine derivative. The method of synthesis here reported for the benzimidamides $\mathbf{5 a}$ and $\mathbf{6 b}$ can therefore be applied for the preparation of new amidines of type $\mathrm{RC}(=\mathrm{NH}) \mathrm{NHR}$ where the NHR fragment is the model nucleobase 1-methylcytosine or 9-methyladenine,

\section{Acknowledgements}

Dr D. Montagner thanks the University of Padua for the postdoc fellowship.

\section{References}

1 J. A. Gautier, M. Miocque and C. C. Farnoux, in The Chemistry of Amidines and Imidates, Vol. 1 (Ed., S. Patai), John Wiley, New York, 1975, pp. 283-348; G. V. Boyd, in The Chemistry of Amidines and Imidates, Vol. 2 (ed. S. Patai and Z. Rappoport), John Wiley, New York, 1991, pp. 367-424.

2 J. V. Greenhill and P. Lue, Prog. Med. Chem., 1993, 30, 203-326.

3 F. C. Schäfer and A. P. Krapcho, J. Org. Chem., 1962, 27, 1255-1258.

4 M. W. Partridge and W. F. Short, J. Org. Chem., 1947, 390-394.

5 H. Jendralla, B. Seuring, J. Herchen, B. Kulitzscher, J. Wunner, W. Stuber and R. Koschinsky, Tetrahedron, 1995, 51, 12047-12068; A. Dondoni and G. Barbaro, J. Chem. Soc., Chem. Commun., 1975, 761762; R. E. Bolton, S. J. Coote, H. Finch, A. Lowdon, N. Pegg and M. V. Vinader, Tetrahedron Lett., 1995, 36, 4471-4474.

6 H. U. Stilz, B. Jablonka, M. Just, J. Knolle, E. F. Paulus and G. Zoller, J. Med. Chem., 1996, 39, 2118-2122; C. Schnur, J. Org. Chem., 1979, 44, 3726-3727; F. C. Schaefer and G. A. Peters, J. Org. Chem., 1961, 26, 412-418; A. Thurkauf, J. Labelled Compd. Radiopharm., 1997, 39, 123-128; J. B. Kirby, N. A. van Dantzig, C. K. Chang and D. G. Nocera, Tetrahedron Lett., 1995, 36, 3477-3480; J. B. Medwid, J. Med. Chem., 1990, 33, 1230-1241.

7 V. Y. Kukushkin and A. J. L. Pombeiro, Chem. Rev., 2002, 102, 17711802.

8 J. Barker, M. Kilner, M. M. Mahmoud and S. C. Wallwork, J. Chem. Soc., Dalton Trans., 1989, 837-841; S. Mazzega Sbovata, R. A. Michelin, M. Mozzon, A. Venzo, R. Bertani and F. Benetollo, Inorg. Chim. Acta, 2010, 363, 487-494; S. Mazzega Sbovata, F. Bettio, C. Marzano, M. Mozzon, R. Bertani, F. Benetollo and R. A. Michelin, Inorg. Chim. Acta, 2008, 361, 3109-3116; G. H. Sarova, N. A. Bokach, A. A. Fedorov, M. N. Berberan-Santos, V. Y. Kukushkin, M. Haukka, J. J. R. Frausto da Silva and A. J. L. Pombeiro, Dalton Trans., 2006, 3798-3805; P. V. Gushchin, M. Haukka, N. A. Bokach and V. Y. Kukushkin, Russ. Chem. Bull., 2008, 57, 2125-2131; N. A. Bokach, T. V. Kuznetsova, S. A. Simanova, M. Haukka, A. J. L. Pombeiro and V. Y. Kukushkin, Inorg. Chem., 2005, 44, 5152-5160.

9 B. Longato, D. Montagner, G. Bandoli and E. Zangrando, Inorg. Chem., 2006, 45, 1805-1814.

10 D. Montagner, A. Venzo, E. Zangrando and B. Longato, Inorg. Chem., 2010, 49, 2103-2110.

11 M. N. Kopylovich and A. J. L. Pombeiro, Coord. Chem. Rev., 2011, 255, 339-355. 
12 D. Montagner, E. Zangrando and B. Longato, Inorg. Chem., 2008, 47, $2688-2695$.

13 L. Schenetti, A. Mucci and B. Longato, J. Chem. Soc., Dalton Trans. 1996, 299-303.

14 E. G. Talman, W. Brüning, J. Reedijk, A. L. Spek and N. Veldman, Inorg. Chem., 1997, 36, 854-861.

15 T. J. Kistenmacher, M. Rossi, J. P. Caradonna and L. G. Marzilli, Adv. Mol. Relax. Interact. Processes, 1979, 15, 119133.

16 Z. Otwinowski and W. Minor, Processing of X-ray Diffraction Data Collected in Oscillation Mode, In Methods in Enzymology, ed. C. W. Carter Jr. and R. M. Sweet, Academic Press, New York, 1997, Vol. 276, p 307-326.

17 G. M. Sheldrick, Acta Crystallogr., Sect. A: Found. Crystallogr., 2008, 64, 112-122.
18 L. J. Farrugia, J. Appl. Crystallogr., 1999, 32, 837-838.

19 D. Montagner and B. Longato, Inorg. Chim. Acta, 2008, 361, 16761680.

20 D. C. Prevorsek, J. Phys. Chem., 1962, 66, 769-778

21 I. El Drubi Vega, P. A. Gale, M. E. Light and S. J. Loeb, Chem. Commun., 2005, 4913-4915.

22 W. H. Press, B. P. Flannery, S. A. Teukolsky and W. T. Wetterling, Numerical Recipies. The Art of Scientific Computing, Cambridge U. P., Cambridge, 1986, p. 523.

23 G. G. Hammes and H. O. Spivey, J. Am. Chem. Soc., 1966, 88, 16211625; K. Yamamoto and N. Nishi, J. Am. Chem. Soc., 1990, 112, 549 558.

24 G. P. Johari and G. Sartor, J. Phys. Chem. B, 1997, 101, 8331-8340.

25 D. Montagner, V. Gandin, C. Marzano and B. Longato, J. Inorg. Biochem., 2011, 105, 919-926. 